IZA DP No. 7858

Which Children Stabilize Marriage?

Héctor Bellido

José Alberto Molina

Anne Solaz

Elena Stancanelli

December 2013 


\title{
Which Children Stabilize Marriage?
}

\author{
Héctor Bellido
}

University of Zaragoza

José Alberto Molina

University of Zaragoza

and IZA

Anne Solaz

Institut National d'Études Démographiques (INED)

\author{
Elena Stancanelli
}

CNRS Centre d'Économie de la Sorbonne, Paris School of Economics and IZA

\section{Discussion Paper No. 7858 \\ December 2013}

\author{
IZA \\ P.O. Box 7240 \\ 53072 Bonn \\ Germany \\ Phone: +49-228-3894-0 \\ Fax: +49-228-3894-180 \\ E-mail: iza@iza.org
}

\begin{abstract}
Any opinions expressed here are those of the author(s) and not those of IZA. Research published in this series may include views on policy, but the institute itself takes no institutional policy positions. The IZA research network is committed to the IZA Guiding Principles of Research Integrity.

The Institute for the Study of Labor (IZA) in Bonn is a local and virtual international research center and a place of communication between science, politics and business. IZA is an independent nonprofit organization supported by Deutsche Post Foundation. The center is associated with the University of Bonn and offers a stimulating research environment through its international network, workshops and conferences, data service, project support, research visits and doctoral program. IZA engages in (i) original and internationally competitive research in all fields of labor economics, (ii) development of policy concepts, and (iii) dissemination of research results and concepts to the interested public.
\end{abstract}

IZA Discussion Papers often represent preliminary work and are circulated to encourage discussion. Citation of such a paper should account for its provisional character. A revised version may be available directly from the author. 


\section{ABSTRACT}

\section{Which Children Stabilize Marriage ${ }^{1}$}

Children can be considered as a marriage-specific investment that increases the value of the marriage, making a divorce more costly. We exploit the richness of pre- and post-marital information from the National Longitudinal Survey of Youth 79, for the United States, to investigate the relation between fertility and marriage instability. In our model of marriage breakdown, we use the number of siblings of the respondent and, alternatively, multiple births, to instrument the number of children conceived during first marriage. Our results indicate that the presence of children significantly reduces the probability of marital disruption. In addition, the younger the children, the greater the deterrent effect. In contrast, we conclude that children conceived before first marriage increase the risk of marital disruption. Finally, the higher the parents' level of education, the larger the positive effect of fertility on marital stability.

JEL Classification: J12, J13, J19

Keywords: children, marriage, divorce, IV approach

Corresponding author:

José Alberto Molina

Department of Economic Analysis

University of Zaragoza

Gran Vía 2

50005 Zaragoza

Spain

E-mail: jamolina@unizar.es

${ }^{1}$ The authors are grateful for financial support from the Science, Technology and University Department of the Government of Aragon (grant reference number B094/09), and the Spanish Ministry of Economics (Project ECO2012-34828) as well as the Institut National d'Études Demographiques (INED). This paper was partially written while José Alberto Molina was Visiting Fellow at the Department of Economics of Boston College (U.S.), to which he would like to express his thanks for the hospitality and facilities provided. The usual disclaimers are applied. The responsibility for their analysis and conclusions presented in this article belongs solely to the authors. 


\section{1. - INTRODUCTION}

Over the last five decades, divorce in the United States has undergone dramatic changes. The divorce rate increased dramatically from the early 1960s to the early 1980s, and then began a steady decline (see Figure 1 ). ${ }^{2}$ This goes together with upward trends in the number of singleparent families, in cohabitation rates, and in the mean age at first marriage, and with a continuing decline in the number of traditional families, consisting of a breadwinner-husband and a homemaker-wife (Gruber 2004; Wolfers 2006). On the other hand, the average population under 18 years old - per household or per family - also dropped sharply from the early 1960s to the early 1980s, then stabilized and even grew slightly, suggesting that these trends may be correlated. ${ }^{3}$ In this paper, we analyze the impact of the number of children conceived during first marriage on the risk of marital disruption of the couple, adopting an instrumental variable approach. ${ }^{4}$ If children represent a marriage-specific investment, then the greater the number of children, the less likely the event of divorce. However, since happier marriages may also lead to more children, all other things being equal, it is important to instrument fertility when modelling the probability of divorce, in order to deal with endogeneity concerns. We study the negative effect of children on their parents' divorce probability, focusing particularly on whether they are conceived before or after marriage, on their age, and on whether they are raised by educated parents, or not. To that end, we exploit the many waves available to date of the National Longitudinal Survey of Youth 1979 (NLSY79), which enables us to observe individuals from their early childhood onwards, until they first marry, have children and, eventually, divorce.

This issue is important for welfare purposes. Prior research has shown that divorce leads to negative child outcomes (see, for a review, Amato 2004) in terms of worse academic, emotional, and health outcomes (Evenhouse and Reilly 2004; Fronstin et al. 2001; Gruber 2004), in addition to having negative economic, well-being, and health effects for the divorcees

\footnotetext{
2 The Crude Divorce Rate - defined as the annual number of divorces per 1,000 mid-year population - began to increase by the year 1960, reaching its maximum value of 5.27 in 1981. From that point, this indicator leveled off to 3.5 divorces per 1,000 in the year 2007. Data come from several issues of the UN Demographic Yearbook and the Organization for Economic Cooperation and Development (OECD).

${ }^{3}$ See data from the U.S. Census Bureau.

${ }^{4}$ Children conceived during first marriage do not include those children who were born during the first eight months of marriage, or before the marriage took place.

The marital dissolution can be reported by declaring that the marital status is separated or divorced. However, since every person in our sample is married, not cohabiting, and the marital status "separated" normally is the threshold of legal divorce, we make no distinction, following Chan and Halpin (2002).
} 
themselves (see, for example, Amato 2004; Ananat and Michaels 2008; Williams and DunneBryant 2006). Since parents are quite likely to anticipate at least some of these adverse effects, their propensity to divorce may be reduced, relative to childless couples. Thus, the number of children may serve as a deterrent to marital disruption. In this paper, we investigate this possibility.

Our results show that children conceived during first marriage reduce the risk of marital dissolution, when we consider the potential endogeneity of fertility. In contrast, children conceived out of wedlock increase the probability of divorce. Moreover, we produce new evidence for the hypothesis that the effect of the number of children conceived during first marriage on the risk of marital disruption varies depending on the educational level of their parents. We find that more educated parents are less likely to divorce, for a given fertility scenario, confirming Becker's view that children are a marriage-specific investment (Becker 1981) and thus, they are more valuable to more educated parents (see also Black et al. 2005; Currie and Moretti 2003 on the relation between parent education and the "value" of children) and presumably, wealthier parents. Our conclusions are not affected when we specify different models (duration, fixed effects), nor when we adopt different specifications to test the robustness of our estimates.

The remainder of this paper is structured as follows. Section 2 presents a short literature review of the effect of children on the risk of marital dissolution. Section 3 presents our empirical strategy. In Section 4, we describe the data. The results of our estimations follow in Section 5. The last section sets out our conclusions.

\section{2. - LITERATURE REVIEW}

The influence of children on marital stability has been previously analyzed. Andersson (1997), using data from Sweden, finds that children reduce the risk of divorce, especially when they are young, but this effect disappears from the third child onwards, irrespective of the age of the children. Similar conclusions are drawn by Cherlin (1977), who finds that, in the US, children have a deterrent effect on the dissolution of marriage only when they are very young. 
Remarkably, Chan and Halpin (2002), using data for Britain, show that the effect of children on marital stability turned from positive to negative during the 1980s. However, these studies did not explicitly consider the potential endogeneity of children in the marital stability model. Indeed, according to Becker (1981), children represent marriage-specific investments, and as such, they would reduce the risk of marital disruption. However, happier couples are also more likely to have more children, while couples closer to divorce are less likely to conceive children (Myers 1997). Earlier studies addressed the potential endogeneity issue by taking a simultaneous equation approach, often coming to controversial conclusions. Waite and Lillard (1993), using data for the US, conclude that the first child contributes to marital stability, whereas subsequent children have the opposite effect. Steele et al. (2005) find that young children have a stabilizing effect on marital relations, in contrast to older children, who increase the chances that a couple divorces. Koo and Janowitz (1983) conclude that the effect of fertility on divorce is insignificant. Svarer and Verner (2008), applying a timing-of-event method and using a bivariate duration model, conclude that children increase the risk of marital disruption. Finally, Vuri (2001) uses an instrumental variable approach to model the effect of fertility instrumented with the gender of the two previous children - on divorce, finding that children have a positive impact on the risk of marital disruption.

As can be seen, there is controversial, and conflicting, evidence regarding the effect of the number of children on marital disruption. Our paper adds to the existing literature by exploiting the richness of information collected by the NLSY79 to more thoroughly investigate the relationship between the number of children conceived during first marriage and first marriage break-up.

\section{3. - EMPIRICAL STRATEGY}

Let us specify a divorce model as follows:

$$
\text { Divorce }_{\mathrm{it}+1}=\beta_{1} \text { Children }_{\mathrm{it}}+\beta_{2} \mathrm{X}_{\mathrm{it}}+\alpha_{\mathrm{i}}+\varepsilon_{\mathrm{it}}
$$


where Divorce $_{i t+1}$ is a dummy variable that takes value 1 if individual $i$ suffers a marital disruption in year $t+1 .^{5}$ In our estimates, the variable of interest is Children $\mathrm{it}_{\text {, }}$ defined as the number of children conceived during first marriage by individual $i$ until year $t$, and $\mathrm{X}_{\mathrm{it}}$ is a vector of characteristics widely considered as standard determinants of the risk of marital disruption, such as age, level of education, and region of residence. $\alpha_{i}$ is the unknown intercept for each individual in our database, capturing individual unobserved heterogeneity (as, for example, negative attributes that would make someone a less attractive long-term partner), and $\varepsilon_{\mathrm{it}}$ is the error term. ${ }^{6}$ We control for the individual characteristics in year $\mathrm{t}$ for a divorce decision taken in year $t+1$, in order to be able to ensure that the covariates are pre-determined with respect to the decision of marital disruption (see also the discussion below).

However, as pointed out earlier, we need to account for the potential endogeneity of the number of children in this model (see Section 1). Therefore, we specify a two-stage least squares model in which we instrument the number of children conceived during first marriage. As usual under this approach, the instruments need to be correlated with the variable suspected to be endogenous - the number of children conceived during first marriage - but exogenous with respect to the dependent variable -the risk of marital disruption. This requires that the instruments are not correlated with the error term in equation (2). Thus, we estimate the following equations:

$$
\begin{gathered}
\text { Divorce }_{\mathrm{it}+1}=\gamma_{1} \text { Children }_{\mathrm{it}}+\gamma_{2} \mathrm{X}_{\mathrm{it}}+\lambda_{\mathrm{it}} \\
\text { Children }_{\mathrm{it}}=\theta_{1} \mathrm{IV}_{\mathrm{it}}+\theta_{2} \mathrm{X}_{\mathrm{it}}+\mu_{\mathrm{it}}
\end{gathered}
$$

where Divorce ${ }_{i t+1}$ is a dummy variable that takes value 1 if individual $i$ suffers a marital disruption in year $t+1$. Again, we control for the individual characteristics in year $\mathrm{t}$ for a divorce

\footnotetext{
${ }^{5}$ We revisit the definition of the variable divorce below, by expanding its explanation.

${ }^{6}$ Since divorce laws vary by state, (Cáceres-Delpiano and Giolito 2008), and they have an impact on the probability of divorce (Friedberg 1998; Wolfers 2006), we control for the area of residence. Non-American researchers do not have access to information on the place of residence. As can be read on the web page of the Bureau of Labor Statistics: "To protect respondent confidentiality, the NLS public-use files do not include geographic variables such as state, county, and metropolitan area” http://www.bls.gov/nls/nlsfaqs.htm\#anch25; "The Bureau of Labor Statistics (BLS) only grants access to geocode files for researchers in the United States who agree in writing to adhere to the BLS confidentiality policy and whose projects further the mission of BLS and the NLS program to conduct sound, legitimate research in the social sciences. Applications from abroad cannot be accepted.” http://www.bls.gov/nls/nlsfaq2.htm\#anch32. However, we use the geographical information available to us in the data which divides the U.S. territory into four regions: North East, North Central, South, and West, with North East being the reference region in the analysis.
} 
decision made in year $t+1$, Children $_{i t}$ indicates the number of children conceived during the marriage, and $\mathrm{X}_{\mathrm{it}}$ is a set of personal, household, and partner characteristics of individual "i”.

We explore two different options that meet the requirements to be valid instruments. First, we create a series of dummy variables for the number of siblings of the individual, for no siblings (the reference group), only one, two, three, or four or more siblings. The notion behind these variables is that individuals are likely to replicate the fertility behavior of their parents (as documented, for example, in Axinn et al. 1994; Booth and Kee 2006). Alternatively, we use as instrument for fertility the presence of a multiple birth during first marriage, and we construct a dummy variable that takes value 1 if the respondent has twins, triplets, or more. ${ }^{7}$ We expect that the presence of an unplanned child (as a consequence of a multiple birth) is not related to the probability of marital disruption (Jacobsen et al. 2001). ${ }^{8}$

\section{4. - DATA AND VARIABLES}

We use data from the National Longitudinal Survey of Youth 1979 (NLSY79), a well-known and widely-researched USA survey that began sampling, in 1979, 12,686 young men and women born between 1957 and 1965 (thus, aged between 14 and 22 years old in 1979, the year of the first wave). These individuals were interviewed each following year until 1994, and from then onwards, every two years (in even-numbered years). The survey collects detailed information on individual marital and fertility histories, family background, educational experience, labor market behavior, health issues, and assets and incomes, among many other factors. We checked whether sample selection bias is caused by attrition in this survey panel data. We used a probit on the probability of participating in the subsequent wave, finding that individuals in intact households have the same chances to participate in the following waves as divorced individuals.

We focus on first marriages and consider individuals from the first marriage onwards. Thus, we select a sample of individuals who were at least 21 years old when they first married,

\footnotetext{
${ }^{7}$ Cáceres-Delpiano (2012) also uses the presence of a multiple birth as an instrumental variable for family size.

${ }^{8}$ Although the exogeneity of such an instrument is debatable, individuals may be able to anticipate their chances of having a multiple birth, for example due to various types of fertility treatments or inherited genes, minimizing its impact on marital stability.
} 
since marrying earlier most often applies to individuals without college education, and we are interested in studying the relation between fertility, divorce, and education. However, we also experiment by including all first marriages in the sample (see Section 4). We dropped higher order marriages from the analysis, as well as those individuals whose first marriage ends with the death of the spouse (these were very rare cases).

Our dependent variable is a dichotomous indicator of whether the individual is still married, or divorced. The covariates are measured from the prior year to ensure that they are pre-determined with respect to the moment of the decision of marital disruption. Otherwise, the covariates could have already suffered variations due to a divorce experienced in the same year, since information is only collected once per year. The number of children only includes those conceived during the first marriage. Therefore, children born before or during the first 8 months of marriage are considered to be conceived out of marriage and are not included. ${ }^{9}$

Our sample includes 5,622 individuals in their first marriage. Table 1 presents the summary statistics for this sample, while Table 1.1 shows similar descriptives for the two subsamples, of divorcees, and individuals in intact marriages. Among the first subsample, the mean age at first marriage is 24.5 while the mean age at divorce is almost 32. For the subsample of intact marriages, the average age at first marriage is very similar, at 25.1 years old. Individuals in an intact marriage relationship have an average of 0.42 more children than those whose marriage ended - of course, this may be simply due to the fact that we may observe them longer as they did not divorce during the sample period. In addition, those who remain married during the observation period have a higher level of education. The percentage of blacks among those who remain married is 10 points lower than among those who experience marital disruption.

\section{5. - RESULTS OF ESTIMATION}

While the presence of children in a marriage acts as a deterrent to marital disruption, it is also likely that couples with more marital problems - who are thus more likely to divorce - have a

\footnotetext{
${ }^{9}$ We have re-estimated our main estimates excluding those individuals with children conceived before or during the first eight months of marriage. Results are quite similar.
} 
lower probability of having children. To deal with this endogeneity concern, we apply an instrumental variable approach. We add to the existing literature on divorce by exploiting a new set of instruments drawn from the NLSY79 survey.

We create two different sets of variables. First, we use five dummies indicating whether the individual has no siblings, or has one, two, three, or four or more siblings (see earlier for discussion). Second, we use a dummy for whether the respondent had a multiple birth during first marriage (see the earlier discussion). We also include both sets of instruments in the same regression.

As expected, a greater number of siblings and the presence of a multiple birth during first marriage are both positively related to fertility during first marriage. Results of this first step are shown in Table A of Appendix A. ${ }^{10}$

Columns (1), (2) and (3) of Table 2 show the results of the IV model using the number of siblings, the presence of a multiple birth, and both sets of instruments together, respectively, to instrument the number of children conceived during first marriage in our model of the probability of divorce. ${ }^{11}$

For all sets of instruments, the effect of the number of children conceived during first marriage on the probability of marital disruption is negative and significant at the $1 \%$ level. With respect to the other covariates, we find a U-shaped inverse relationship between age and the risk of marital disruption. The probability of divorce is significantly larger in couples where the husband is more than five years older than the wife. Individuals who married younger are also more likely to break up. With respect to the level of education, the higher the level, the lower the probability of marital disruption. Individuals who lived in a household without the father when they were younger are more likely to end their marriage than the others, all other things being equal. The probability of marriage disruption increases with higher risk attitudes

\footnotetext{
${ }^{10}$ As a first step, we regress the variable suspected to be endogenous - number of children conceived during first marriage - using the same set of explanatory variables as in our baseline estimates of the probability of marital disruption, but now including a set of excluded instruments correlated with the variable suspected to be endogenous and independent of the error term.

${ }^{11}$ We test the validity of our instruments by applying a test of over-identifying restrictions, whose null hypothesis is that the excluded instruments are valid instruments, i.e., uncorrelated with the error term and correctly excluded from the estimated equation. Following this strategy, we confirm the validity of our instruments.
} 
during youth (measured by the variable for being charged with any illegal activity), with children conceived before first marriage, or with being black.

\section{ROBUSTNESS CHECKS}

We checked whether our estimates are sensitive to the definition of fertility, the sample selection cut, and the inclusion of other covariates not included earlier in our main model due to certain endogeneity concerns (see Tables 3 to 7).

First, we include in the sample those individuals who married very young (before age 21). This leads to a sample of 8,303 individuals. The estimates of the model for this larger sample are given in Table 3. We find that children conceived during first marriage are a deterrent to marital disruption, and this variable is significant at the $1 \%$ level. The effect of the remaining covariates on the probability of marital disruption is also very similar to the findings from the main specification.

Next, we experiment with an alternative definition of fertility. Steele et al. (2005) and Waite and Lillard (1991) conclude that the effect of children as a deterrent to marital disruption is stronger when they are younger. To test for this hypothesis, we redefine fertility to include only those children conceived during first marriage who are younger than 10 years old, and, alternatively, only those younger than 6 years old. The results for these alternative specifications are presented in Table 4. For all sets of instruments, the younger the children conceived during first marriage, the greater their deterrent effect on marital disruption. Specifically, the deterrent effect of children under 10 increases between $13 \%$ and $21 \%$ with respect to all children conceived during first marriage, depending on the instruments used. When we only consider children under 6 the increase in the deterrent effect ranges from $26 \%$ to $53 \%$. This is in line with earlier work in the area.

Some of the existing literature on the causes of marital disruption focuses on the disruptive effect of children conceived before the current marriage, a variable that we had excluded from our baseline regression. We now redefine the variable fertility to include those children conceived before first marriage. We expect to find a decrease in the deterrent effect of children 
on the probability of marriage disruption, relative to that obtained in our baseline estimates, in which we had only included children conceived during first marriage.

Table 5 shows that the variable measuring the number of children is still inversely related to the risk of marital disruption and statistically significant for all the instrumental variables used. However, the magnitude of the effect decreases, as expected. Specifically, the reduction in the deterrent effect of children to marital disruption ranges from $33 \%$ to $43 \%$, depending on the instruments used.

In Table 6, we include the variables indicating the number of children conceived during first marriage and before first marriage, separately. Both variables are potentially endogenous to the risk of marital disruption. ${ }^{12}$ For this reason, we include in this specification additional instruments for children conceived before the first marriage.

We use information on the age at which respondents had their first sexual intercourse, since the earlier the sexual initiation, the greater the risk of becoming pregnant, and therefore, of having a child before first marriage (Miller and Heaton 1991). Specifically, we include a set of dummies to indicate whether the respondent had his/her first sexual intercourse before the age of 16 years, between 16 and 18 years, after 18 years, or had never had sex by the years 19831985, when respondents were between 21 and 28 years old (the question about first sexual intercourse is only available in those waves). We select these intervals of age since the mean age of first intercourse after menarche for women aged 15-44 was 17.4 in 2002, and the mean age of first intercourse for men aged 15-44 is 17.0, also in 2002 (Chandra et al. 2005; Martínez et al. 2006).

Results are presented in Table 6. We find a negative effect of children conceived during first marriage on the risk of marriage disruption. In contrast, children conceived before first marriage have a positive effect on marital dissolution. Moreover, the instruments included for children conceived before first marriage have the expected effect. The fact of having had first sexual intercourse before age 16 has a positive and statistically significant effect on the probability of conceiving children before the first marriage, as does the fact of having had first

\footnotetext{
${ }^{12}$ Children conceived before first marriage induce the so-called shotgun marriages, which are less likely to last.
} 
sexual intercourse between ages 16 and 18, and later than 18 years old, with respect to those who never had sex, though this last effect is smaller is size.

Table 7 presents results of our estimation of the main model with additional covariates, namely other personal and family characteristics, that may contribute to a determination of the probability of marital disruption. These elements were excluded from our baseline estimates because of endogeneity concerns. ${ }^{13}$ Column (1) shows our baseline estimates. ${ }^{14}$ Since members of those couples with a higher risk of marital disruption may work longer hours to increase their income, in anticipation of a possible future divorce (Johnson and Skinner 1986), including variables for family income may bias our results due to endogeneity concerns. We use the “OECD modified equivalized scale” income indicator in our estimates, along with its square, in Column (2). ${ }^{15}$ This equivalized income indicator shows a U-shaped relationship to the probability of marital disruption, indicating that as the family income indicator increases, the risk of marital dissolution decreases, but at some point this relationship turns and the probability of marital disruption begins to increase. Prior research has shown that higher incomes decrease the risk of marital dissolution, especially in the case of males (Burgess et al. 2003). We can see that the effect of the number of children conceived during first marriage on the risk of marital disruption remains negative and statistically significant.

In Column (3), we include variables indicating the religion under which the respondent was raised (Vaaler et al. 2009). Since religion establishes behaviors that are morally accepted, or rejected, if there is a process that jointly determines personal religious beliefs and the propensity to break up one's marriage, then including controls for religious attitudes may bias our results. It turns out that the results are robust to these inclusions.

In Column (4), we add as an additional control a dummy for residing in an urban or in a rural area. Thus, again, if there is a process that simultaneously affects the probability of living in a rural or in an urban area and a propensity to marital disruption, including a dummy

\footnotetext{
${ }^{13}$ Here, we use as instrumental variables dummies for the number of siblings of the respondents and a dummy indicating the presence of a multiple birth simultaneously, due to space constraints. We have shown that using these sets of instruments separately does not affect the main conclusions from our model. Results using both sets of instruments separately are very similar.

${ }^{14}$ This column shows the specification with both sets of instruments simultaneously, to facilitate the comparison.

15 This indicator takes into account not only the family income, but also the number and the age of each member of the household. This indicator assigns a value of 1 to the respondent, a value of 0.5 to each additional member aged 14 or older, and a value of 0.3 to each household member under age 14 (thus, the coefficient attributed to a two-parent family with two small children is 2.1)
} 
indicating whether the individual lives in a rural or in an urban setting may bias our results. Our estimates show that the number of children conceived during first marriage maintains its negative effect on marital instability. Living in an urban area has a positive effect on the risk of marital disruption as expected, but it is not statistically significant.

Column (5) includes controls for the employment of the respondent and his/her spouse, which we do not include in our baseline model due to endogeneity concerns. As stated above, members of couples with higher probabilities of divorce may change their labor force participation in the years prior to a marital disruption (Johnson and Skinner 1986). The results of the estimation indicate that the fact that both the respondent and their partner are working is related to a decrease in the probability of marital disruption. Again, the effect of children conceived during first marriage on marital disruption remains negative and statistically significant.

In Column (6), we show the results of estimating a model in which we include all these additional controls, to conclude that our results are robust to these inclusions. In particular, the negative impact of children conceived during first marriage on the risk of marriage break-up is comparable in size to that from our main specification (Column (1)), and statistically significant.

\section{HETEROGENEITY OF RESPONSES BY LEVEL OF EDUCATION}

Children conceived during first marriage are marriage-specific investments, increasing the value of the marriage and making it more valuable and therefore more difficult to break (Becker 1981). It has been shown that there exists a mechanism of inter-generational transmission of human capital from parents to their offspring (Black et al. 2005; Currie and Moretti 2003). Thus, we would expect that the investment made by parents with a higher level of human capital would be greater than that made by other couples, assuming positive assortative mating, which is generally plausible. Consequently, the relationship between fertility and marital disruption may be very different as a function of parental education. 
To test this hypothesis, we re-estimate the model, splitting the sample according to the level of education of the respondent (see Table 8). We find no evidence of the deterrent effect of children on marital disruption for the subsample of respondents with the lowest level of education. We do find evidence of a decrease in the risk of marital disruption for any additional child for respondents with intermediate and higher levels of education. The decrease in the risk of marital disruption is $13 \%$ more for the highest educated respondents than for those with an intermediate level of education.

Thus, we conclude that the negative effect on marital disruption of children conceived during first marriage is not homogeneous with the parent's education. Those couples with greater human capital - as measured by their educational level - seem to make a greater investment in child marriage-specific capital than couples with lower human capital. ${ }^{16}$

We also show both Random Effects and Fixed Effects specifications for the model of marital disruption by level of education (see Table B in Appendix A). Under either approach, children conceived during first marriage have no effect on the risk of marital disruption for individuals with the lowest level of education in the sample. On the contrary, children have a negative and statistically significant effect on the risk of marital dissolution of respondents with intermediate or higher levels of education. Furthermore, for the highest educated subsample, the negative impact of the number of children on the probability of marital disruption is between $33 \%$ and $54 \%$ greater than for the subsample of respondents with an intermediate educational level.

We also present in Table $\mathrm{C}$ of Appendix A an alternative robustness check. There, we show the results of estimations applying Random Effects and Fixed Effects, rather than using our main model of Instrumental Variables. We find that the effect of the number of children conceived during first marriage on the risk of marital disruption is negative and statistically significant. Furthermore, the magnitude of this impact is the same in Columns (1), (2) and (3), which show results using Random Effects, and in Column (4), which shows results from

\footnotetext{
${ }^{16}$ Since one may argue that financial difficulties might also come into play here, we have re-estimated the model including a measure of household income according to the "OECD modified equivalized scale”. The results are very comparable.
} 
applying a Fixed Effects model. ${ }^{17}$ This result is in the same line as our baseline estimates using an Instrumental Variable approach.

This result, again, supports prior studies that found that the presence of children has a deterrent effect on the likelihood of marriage dissolution, both in the US (South 2001; Weiss and Willis 1997) and in several European countries (Andersson 1997; Jalovaara 2001) and contradicts studies that found a positive effect or no effect (see Section 2 for a discussion). According to the Fixed Effects model, each additional child conceived during first marriage produces a decrease of 0.015 in the probability of marital disruption. Considering that the probability of marital disruption in the sample of first marriages is 0.37 (Table 1.1), having a child would imply a decrease in the risk of marital disruption of 4 percentage points.

As far as the other explanatory variables go, men are slightly less likely to divorce or separate than women - this is perhaps in line with findings by sociologists, who find that women more often initiate divorce. We find a U-shaped inverse relationship between the age of the respondent and the risk of marital dissolution, indicating that younger and older couples have a lower risk of divorce than middle-aged couples. The risk of divorce increases with the age difference between the spouses. We also find that lower levels of education result in a higher probability of marital disruption. The presence of the father in the household in 1979 - rather than being deceased or living elsewhere - when the respondent was aged between 14 and 22, reduces the probability of the respondent's marital disruption. The respondent charged with some illegal activity during their youth also has a higher probability of marriage break-up. The younger the individual is at first marriage, the greater the probability that the marriage ends in divorce. Individuals who already had children before the first marriage are also more likely to divorce. Finally, black individuals have a higher probability of marital disruption than white individuals (the reference group here). Many of these findings confirm earlier conclusions in the literature. The novelty of our study is that we exploit the NLSY wealth of information to instrument children in the marriage break-up model.

\footnotetext{
${ }^{17}$ According to the Hausman test (Hausman 1978) the use of Fixed Effects is recommended. We also present the estimates using Random Effects as this allows us to estimate the effect of variables that do not vary over time on the probability of marital disruption.
} 
As a final check on the robustness of our findings, we implement a discrete time duration model of marital disruption (see Jenkins 2005 for more details). Equations (4) and (5) show the logistic and complementary log-log discrete time hazard functions, respectively:

$$
\begin{gathered}
\mathrm{p}(\mathrm{t})=[1+\exp (-\mathrm{z}(\mathrm{t}))]^{-1} \\
\mathrm{p}(\mathrm{t})=1-\exp [-\exp (\mathrm{z}(\mathrm{t}))]
\end{gathered}
$$

where $\mathrm{z}(\mathrm{t})=\mathrm{c}(\mathrm{t})+\beta^{\prime} \mathrm{X}$ for a representative individual in year $\mathrm{t}, \mathrm{c}(\mathrm{t})$ is the baseline hazard function, and $\beta^{\prime} \mathrm{X}$ includes an intercept term. We also estimate the complementary clog-log model including unobserved heterogeneity, assuming normal distributed errors.

We present the results of these estimates in Table 9. Columns (1), (2) and (3) display results of using the complementary log-log, logistic, and log-log with unobserved heterogeneity models, respectively.

The first thing that stands out is that the effect on the risk of marital disruption of children conceived during first marriage is very similar to our main specification results, both in terms of the sign of the effect and in terms of statistical significance. With respect to the other covariates, we find no important differences from the results obtained in our baseline model estimates. Only the variables related to age at first marriage are now less statistically significant, although the direction of their impact does not change, which is logical since the variable 'age' in the main model also captures marriage duration indirectly (since age at first marriage is also included among the covariates). As in the main specification, we find a U-shaped inverse relationship between age and the risk of marital disruption, and a positive effect of a large age gap between spouses on the probability of marital disruption. Lower levels of education imply higher probabilities of marital dissolution, as do having been charged with illegal activity in youth, having had a child before first marriage, and being black, while the presence of the father in the household during the youth of the respondent reduces the risk of marital disruption.

\section{6. - CONCLUSIONS}

We study the impact that children conceived during first marriage have on marital stability. This issue is important, since it has been shown that divorce has an adverse effect on the divorcees' 
and on their children's well-being. Since happier couples may have more children than others, it is important to account for the potential endogeneity of fertility decisions in a model of marriage break-up. We add to the literature in this area by exploiting the rich information on pre- and post-marital histories of the participants in the NLSY, with twenty-four waves available to date. Earlier studies come to controversial conclusions concerning the direction of the effect of the number and the age of children on marital stability.

We take an instrumental variable approach by exploiting the information on the number of siblings of the respondent and, alternatively, the presence of a multiple birth during the first marriage, to instrument the number of children conceived during first marriage by the respondent. We find a significant deterrent effect of children conceived during first marriage on the risk of marital disruption.

Our conclusions are robust to several specification tests. We also conclude that the younger the children, the greater their negative effect on the risk of marital disruption. Moreover, we find that children conceived before first marriage have a destabilizing effect. Finally, we conclude that the higher the level of education of the parents, the greater the negative effect of their children on marital instability, suggesting that parental education increases the child marriagespecific investment, in line with the theoretical predictions of Becker. In particular, fertility has no significant effect on the marriage stability of individuals with less than intermediate education.

\section{REFERENCES}

Amato, P. (2004) The Consequences of Divorce for Adults and Children, Journal of Marriage and Family, 62, 1269-1287.

Ananat, E. and Michaels, G. (2008) The Effect of Marital Breakup on the Income Distribution of Women with Children, Journal of Human Resources, 43, 611-629.

Andersson, G. (1997) The Impact of Children on Divorce Risks of Swedish Women, European Journal of Population, 13, 109-145.

Axinn, W., Clarkberg, M. and Thornton, A. (1994) Family Influences on Family Size Preferences, Demography, 31, 65-79.

Becker, G. (1981) A Treatise on the Family, Harvard University Press, Cambridge. 
Black, S., Devereux, P. and Salvanes, K. (2005) Why the Apple Doesn't Fall Far: Understanding Intergenerational Transmission of Human Capital, The American Economic Review, 95, 437-449.

Booth, A. and Kee, H. (2006) Intergenerational Transmission of Fertility Patterns in Britain, IZA DP $N^{o} 2437$.

Burgess, S., Propper, C. and Aassve, A. (2003) The Role of Income in Marriage and Divorce Transitions among Young Americans, Journal of Population Economics, 16, 455-475.

Cáceres-Delpiano, J. (2012) Impacts of Family Size on the Family as a Whole: Evidence from the Developing World, The B.E. Journal of Economic Analysis \& Policy, 12, 1-34.

Cáceres-Delpiano, J. and Giolito, E. (2008) How Unilateral Divorce Affects Children, IZA DP $N^{o}$ 3342.

Chan, T. and Halpin, B. (2002) Children and Marital Instability in the UK, Manuscript, Department of Sociology, University of Oxford.

Chandra, A., Martinez, G., Mosher, W., Abma, J. and Jones, J. (2005) Fertility, Family Planning, and Reproductive Health of U.S. Women: Data from the 2002 National Survey of Family Growth, National Center for Health Statistics, Vital Health Stat, 23. Downloaded from: http://www.cdc.gov/nchs/data/series/sr_23/sr23_025.pdf

Cherlin, A. (1977) The Effect of Children on Marital Dissolution, Demography, 14, 265-272.

Currie, J. and Moretti, E. (2003) Mother's Education and the Intergenerational Transmission of Human Capital: Evidence from College Openings, The Quarterly Journal of Economics, 118, 1495-1532.

Evenhouse, E. and Reilly, S. (2004) A Sibling Study of Stepchild Well-Being, Journal of Human Resources, 39, 248-276.

Friedberg, L. (1998) Did Unilateral Divorce Raise Divorce Rates? Evidence from Panel Data, The American Economic Review, 88, 608-627.

Fronstin, P., Greenberg, D. and Robins, P. (2001) Parental Disruption and the Labour Market Performance of Children When They Reach Adulthood, Journal of Population Economics, 14, 137-172.

Gruber, J. (2004) Is Making Divorce Easier Bad for Children? The Long-Run Implications of Unilateral Divorce, Journal of Labor Economics, 22, 799-833.

Hausman, J. (1978) Specification Tests in Econometrics, Econometrica, 46, 1251-1271.

Jacobsen, J., Pearce III, J. and Rosenbloom, J. (2001) The Effects of Child-bearing on Women's Marital Status: Using Twin Births as a Natural Experiment, Economics Letters, 70, 133-138.

Jalovaara, M. (2001) Socio-Economic Status and Divorce in First Marriages in Finland 1991-93, Population Studies, 55, 119-133.

Jenkins, S. (2005) Survival Analysis. Institute for Social and Economic Research, University of Essex. Download from: https://www.iser.essex.ac.uk/files/teaching/stephenj/ec968/pdfs/ec968lnotesv6.pdf.

Johnson, W. and Skinner, J. (1986) Labor Supply and Marital Separation, The American Economic Review, 76, 455-469.

Koo, H. and Janowitz, B. (1983) Interrelationships between Fertility and Marital Dissolution: Results of a Simultaneous Logit Model, Demography, 20, 129-145.

Martínez, G., Chandra, A., Abma, J., Jones, J. and Mosher, W. (2006) Fertility, Contraception, and Fatherhood: Data on Men and Women from Cycle 6 (2002) of the National Survey of Family Growth, 
National Center for Health Statistics, Vital Health Stat, 23. Downloaded from: http://www.cdc.gov/nchs/data/series/sr_23/sr23_026.pdf

Miller, B. and Heaton, T. (1991) Age at First Sexual Intercourse and the Timing of Marriage and Childbirth, Journal of Marriage and the Family, 53, 719-732.

Myers, S. (1997) Marital Uncertainty and Childbearing, Social Forces, 75, 1271-1289.

South, S. (2001) Time-Dependent Effects of Wives’ Employment on Marital Dissolution, American Sociological Review, 66, 226-245.

Steele, F., Kallis, C., Goldstein, H. and Joshi, H. (2005) The Relationship between Childbearing and Transitions from Marriage and Cohabitation in Britain, Demography, 42, 647-673.

Svarer, M. and Verner, M. (2008) Do Children Stabilize Relationships in Denmark?, Journal of Population Economics, 21, 395-417.

Vaaler, M., Ellison, C. and Powers, D. (2009) Religious Influences on the Risk of Marital Dissolution, Journal of Marriage and Family, 71, 917-934.

Vuri, D. (2001) Fertility and Divorce, European University Institute, Working Paper ECO 2001/5.

Waite, L. and Lillard, L. (1991) Children and Marital Disruption, American Journal of Sociology, 96, 930-953.

Waite, L. and Lillard, L. (1993) A Joint Model of Marital Childbearing and Marital Disruption, Demography, 30, 653-681.

Weiss, Y. and Willis R. (1997) Match Quality, New Information and Marital Dissolution, Journal of Labor Economics, 15, S293-S329.

Williams, K. and Dunne-Bryant, A. (2006) Divorce and Adult Psychological Well-Being: Clarifying the Role of Gender and Child Age, Journal of Marriage and Family, 68, 1178-1196.

Wolfers, J. (2006) Did Unilateral Divorce Laws Raise Divorce Rates? A Reconciliation and New Results, American Economic Review, 96, 1802-1820. 
Figure 1:

Crude Divorce Rate/Average Population Under 18

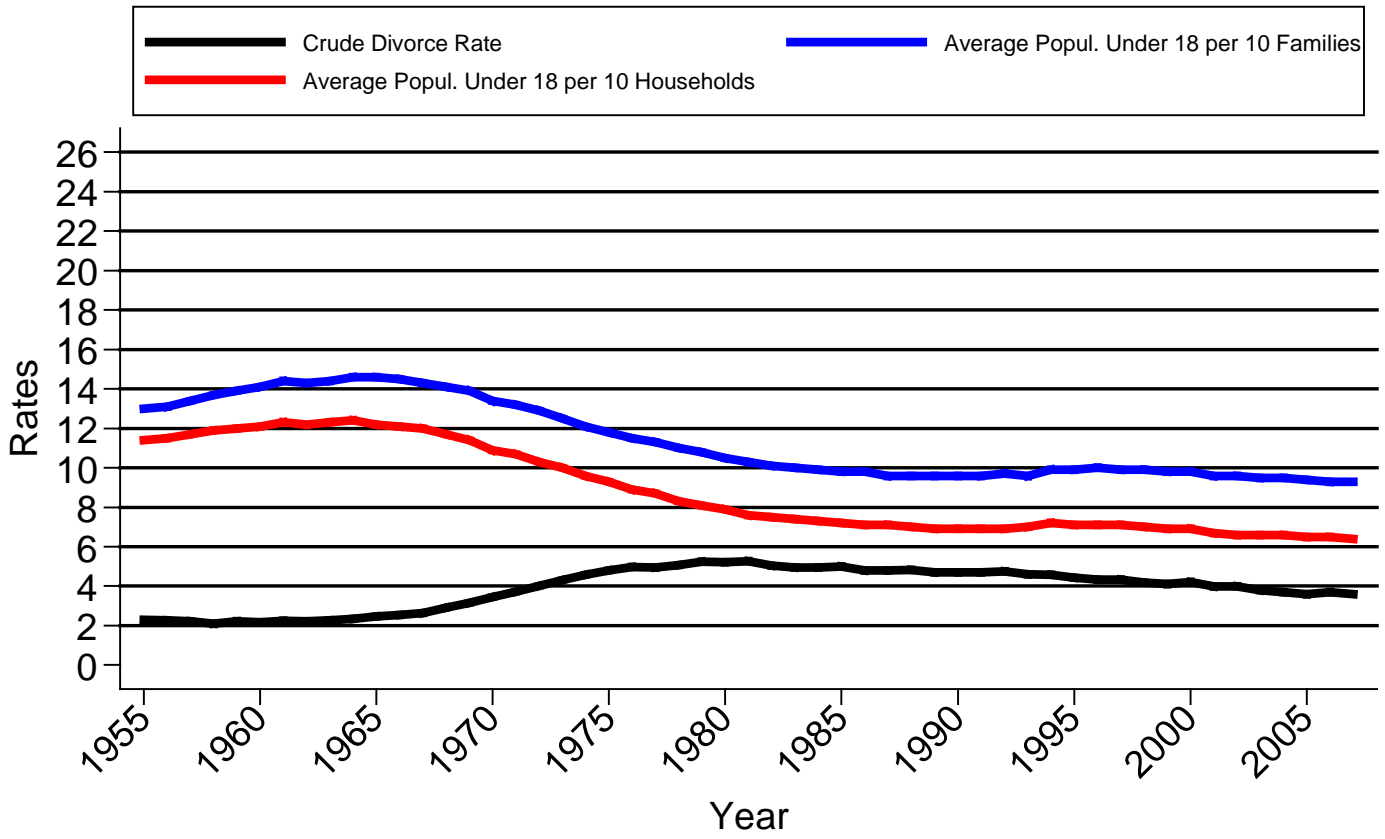

Note: Data from UN Demographic Yearbook, OECD and Census Bureau

NOTES: Data on Crude Divorce Rate come from the UN Demographic Yearbook (several issues) and from the OECD (Organization for Economic Co-operation and Development). Crude Divorce Rate is defined as the annual number of divorces per 1,000 mid-year population. Data on the average population under 18 per 10 households and per 10 families come from United States Census Bureau (http://www.census.gov/population/socdemo/hh-fam/hh6.xls). 
Table 1. - Summary Statistics

(Variables Used in our Baseline Regression)

\begin{tabular}{lcccc}
\hline \multicolumn{1}{c}{ Variables } & Mean & Std. Deviation & Minimum & Maximum \\
\hline Divorce & 0.046 & 0.209 & 0 & 1 \\
Children conceived within marriage & 1.090 & 1.085 & 0 & 10 \\
Gender & 0.534 & 0.499 & 0 & 1 \\
Age & 33.161 & 7.039 & 21 & 51 \\
Age squared & $1,149.228$ & 497.113 & 441 & 2,601 \\
Wife five years older & 0.034 & 0.180 & 0 & 1 \\
Husband five years older & 0.191 & 0.393 & 0 & 1 \\
Same age & 0.775 & 0.417 & 0 & 1 \\
Highest educ.: lowest level & 0.074 & 0.262 & 0 & 1 \\
Highest educ.: high school level & 0.369 & 0.483 & 0 & 1 \\
Highest educ.: college level & 0.247 & 0.431 & 0 & 1 \\
Highest educ.: more than college level & 0.309 & 0.462 & 0 & 1 \\
Highest educ. spouse: lowest level & 0.087 & 0.282 & 0 & 1 \\
Highest educ. spouse: high school level & 0.386 & 0.487 & 0 & 1 \\
Highest educ. spouse: college level & 0.237 & 0.425 & 0 & 1 \\
Highest educ. spouse: more than college level & 0.289 & 0.453 & 0 & 1 \\
Father in household in 1979 & 0.679 & 0.467 & 0 & 1 \\
Without father figure in 1979 & 0.010 & 0.102 & 0 & 1 \\
Father out household in 1979 & 0.311 & 0.463 & 0 & 1 \\
Charged illegal by 1980 & 0.073 & 0.261 & 0 & 1 \\
Age first marriage & 24.925 & 3.893 & 21 & 49 \\
Child before marriage & 0.154 & 0.361 & 0 & 1 \\
Race: Hispanic & 0.163 & 0.370 & 0 & 1 \\
Race: black & 0.191 & 0.393 & 0 & 1 \\
Race: other & 0.646 & 0.478 & 0 & 1 \\
Observations / Respondents & $45632 / 5622$ & & &
\end{tabular}

Notes: This table contains the main summary statistics of variables in our baseline estimates, including the dependent variable, our variable of interest, and the rest of the covariates included in our analysis.

Table 1.1 - Summary Statistics

(People Divorced at Anytime/People Never Divorced)

\begin{tabular}{lcc}
\hline \hline \multicolumn{1}{c}{ Variables } & Those Divorced at Anytime & Those Not Divorced \\
\hline Observations / Respondents & $11,240 / 2,094$ & $34,392 / 3,528$ \\
Mean age at divorce & 31.80 & - \\
Mean age at first marriage & 24.47 & 25.07 \\
Mean number children conceived during first marriage & 0.77 & 1.19 \\
\% with lowest level of education & 10.62 & 6.39 \\
\% with high level of education & 44.72 & 34.41 \\
\% with college level of education & 26.21 & 24.22 \\
\% with more than college level of education & 18.44 & 34.98 \\
\% with spouse lowest level of education & 12.15 & 7.58 \\
\% with spouse high level of education & 46.62 & 36.05 \\
\% with spouse college level of education & 23.83 & 23.65 \\
\% with spouse more than college level of education & 17.39 & 32.72 \\
\% with father in household in 1979 & 61.81 & 69.88 \\
\% without father figure in 1979 & 1.37 & 0.94 \\
\% with father out household in 1979 & 36.81 & 29.18 \\
\% with child before marriage & 22.39 & 13.09 \\
\% race: black & 26.41 & 16.71 \\
\% race: Hispanic & 17.90 & 15.84 \\
\% race: other & 55.69 & 67.46 \\
\hline
\end{tabular}

Notes: This table contains the main summary statistics, dividing the sample between those who were divorced at any time, Column (1), and those who do not divorce, Column (2). 
Table 2. - Children Conceived During First Marriage and Risk of Marital Dissolution: Instrumental Variable Approach (Dependent Variable: Risk of Marital Dissolution)

\begin{tabular}{lccc}
\hline \hline & $(1)$ & $(2)$ & $(3)$ \\
\hline Number children conceived within marriage & $-0.237^{* * *}$ & $-0.075^{* * *}$ & $-0.104^{* * *}$ \\
& $(0.074)$ & $(0.020)$ & $(0.020)$ \\
Gender & -0.009 & $-0.008^{* * *}$ & $-0.008^{*}$ \\
Age & $(0.007)$ & $(0.004)$ & $(0.004)$ \\
& $0.125^{* * *}$ & $0.045^{* * *}$ & $0.059^{* * *}$ \\
Age squared & $(0.032)$ & $(0.009)$ & $(0.009)$ \\
& $-0.001^{* * *}$ & $-0.001^{* * *}$ & $-0.001^{* * *}$ \\
Wife five years older & $(0.0004)$ & $(0.0001)$ & $(0.0001)$ \\
Husband five years older & -0.033 & 0.005 & -0.002 \\
& $(0.028)$ & $(0.012)$ & $(0.012)$ \\
Highest education: lowest level & 0.013 & $0.013^{* * *}$ & $0.013^{* * *}$ \\
& $(0.008)$ & $(0.005)$ & $(0.005)$ \\
Highest education: high school level & $0.076^{* * *}$ & $0.044^{* * *}$ & $0.049^{* * *}$ \\
Highest education: college level & $(0.016)$ & $(0.008)$ & $(0.008)$ \\
& $0.048^{* * *}$ & $0.033^{* * *}$ & $0.035^{* * *}$ \\
Highest education spouse: lowest level & $(0.009)$ & $(0.005)$ & $(0.005)$ \\
Highest education spouse: high school level & $0.027^{* * *}$ & $0.024^{* * *}$ & $0.025^{* * *}$ \\
& $(0.007)$ & $(0.005)$ & $(0.005)$ \\
Highest education spouse: college level & $0.024^{* *}$ & $0.025^{* * *}$ & $0.025^{* * *}$ \\
& $(0.010)$ & $(0.007)$ & $(0.007)$ \\
Father in household in 1979 & -0.001 & 0.008 & 0.006 \\
& $(0.008)$ & $(0.005)$ & $(0.005)$ \\
Without father figure in 1979 & -0.003 & 0.006 & 0.004 \\
& $(0.008)$ & $(0.005)$ & $(0.005)$ \\
Charged illegal by 1980 & $-0.020^{* * *}$ & $-0.020^{* * *}$ & $-0.020^{* * *}$ \\
Age first marriage & $(0.008)$ & $(0.004)$ & $(0.005)$ \\
Child before marriage & -0.026 & -0.017 & -0.018 \\
Race: hispanic & $(0.029)$ & $(0.017)$ & $(0.019)$ \\
Race: black & $0.034^{* * *}$ & $0.032^{* * *}$ & $0.033^{* * *}$ \\
Constant & $(0.012)$ & $(0.007)$ & $(0.007)$ \\
Region FE & $-0.035^{* * *}$ & $-0.013^{* * *}$ & $-0.017^{* * *}$ \\
Cohort FE & $(0.009)$ & $(0.003)$ & $(0.002)$ \\
Observations & 0.002 & $0.021^{* * *}$ & $0.018^{* *}$ \\
Number of respondents & $(0.017)$ & $(0.007)$ & $(0.007)$ \\
\hline & $0.022^{*}$ & 0.003 & 0.006 \\
& $(0.013)$ & $(0.006)$ & $(0.007)$ \\
& $0.039^{* * *}$ & $0.034^{* * *}$ & $0.035^{* * *}$ \\
& $(0.010)$ & $(0.005)$ & $(0.006)$ \\
& $-1.278^{* * *}$ & $-0.422^{* * *}$ & $-0.572^{* * *}$ \\
& $(0.346)$ & $(0.093)$ & $(0.092)$ \\
& YES & YES & YES \\
& YES & YES & YES \\
& 45,632 & 45,632 & 45,632 \\
& 5,622 & 5,622 & 5,622 \\
\hline
\end{tabular}

Notes: Children conceived during first marriage include only those children who were born during or after the ninth month of marriage. The sample consists of men and women who were at least 21 years old when they first married. Column (1) shows results using dummies for the number of siblings of respondent as instruments. Column (2) uses as instruments a dummy indicating whether the respondent has experienced a multiple birth. Column (3) presents results after using both sets of instruments simultaneously. *** Significant at the $1 \%$ level, ${ }^{* *}$ Significant at the $5 \%$ level, * Significant at the $10 \%$ level. 
Table 3. - Children Conceived During First Marriage and Risk of Marital Dissolution: Sample of Individuals of All Ages at Marriage

(Dependent Variable: Risk of Marital Dissolution)

\begin{tabular}{|c|c|c|c|}
\hline & $(1)$ & $(2)$ & (3) \\
\hline Number children conceived within marriage & $\begin{array}{c}-0.227 * * * \\
(0.069)\end{array}$ & $\begin{array}{c}-0.067 * * * \\
(0.017)\end{array}$ & $\begin{array}{c}-0.092 * * * \\
(0.016)\end{array}$ \\
\hline Gender & $\begin{array}{c}-0.018 * * * \\
(0.006)\end{array}$ & $\begin{array}{c}-0.010 * * * \\
(0.003)\end{array}$ & $\begin{array}{c}-0.011 * * * \\
(0.004)\end{array}$ \\
\hline Age & $\begin{array}{c}0.104^{* * *} \\
(0.025)\end{array}$ & $\begin{array}{c}0.035^{* * *} \\
(0.006)\end{array}$ & $\begin{array}{c}0.046^{* * *} \\
(0.006)\end{array}$ \\
\hline Age squared & $\begin{array}{c}-0.001 * * * \\
(0.0003)\end{array}$ & $\begin{array}{c}-0.0004^{* * *} \\
(0.00007)\end{array}$ & $\begin{array}{c}-0.001 * * * \\
(0.0001)\end{array}$ \\
\hline Wife five years older & $\begin{array}{l}-0.026 \\
(0.026)\end{array}$ & $\begin{array}{c}0.009 \\
(0.011)\end{array}$ & $\begin{array}{c}0.004 \\
(0.011)\end{array}$ \\
\hline Husband five years older & $\begin{array}{l}0.013^{*} \\
(0.007)\end{array}$ & $\begin{array}{c}0.011^{* * *} \\
(0.004)\end{array}$ & $\begin{array}{l}0.011^{* *} \\
(0.005)\end{array}$ \\
\hline Highest education: lowest level & $\begin{array}{c}0.115^{* * * *} \\
(0.022)\end{array}$ & $\begin{array}{c}0.062 * * * \\
(0.007)\end{array}$ & $\begin{array}{c}0.069 * * * \\
(0.008)\end{array}$ \\
\hline Highest education: high school level & $\begin{array}{c}0.052 * * * \\
(0.009)\end{array}$ & $\begin{array}{c}0.035 * * * \\
(0.005)\end{array}$ & $\begin{array}{c}0.037 * * * \\
(0.005)\end{array}$ \\
\hline Highest education: college level & $\begin{array}{c}0.016^{* *} \\
(0.008)\end{array}$ & $\begin{array}{c}0.021^{* * *} \\
(0.005)\end{array}$ & $\begin{array}{c}0.021^{* * *} \\
(0.005)\end{array}$ \\
\hline Highest education spouse: lowest level & $\begin{array}{c}0.009 \\
(0.009)\end{array}$ & $\begin{array}{c}0.019 * * * \\
(0.006)\end{array}$ & $\begin{array}{c}0.018^{* * *} \\
(0.006)\end{array}$ \\
\hline Highest education spouse: high school level & $\begin{array}{l}-0.011 \\
(0.009)\end{array}$ & $\begin{array}{c}0.005 \\
(0.005)\end{array}$ & $\begin{array}{c}0.003 \\
(0.005)\end{array}$ \\
\hline Highest education spouse: college level & $\begin{array}{c}-0.011 \\
(0.009)\end{array}$ & $\begin{array}{c}0.005 \\
(0.005)\end{array}$ & $\begin{array}{c}0.003 \\
(0.005)\end{array}$ \\
\hline Father in household in 1979 & $\begin{array}{c}-0.025^{* * *} \\
(0.006)\end{array}$ & $\begin{array}{c}-0.021^{* * *} \\
(0.004)\end{array}$ & $\begin{array}{c}-0.021 * * * \\
(0.004)\end{array}$ \\
\hline Without father figure in 1979 & $\begin{array}{l}-0.016 \\
(0.025)\end{array}$ & $\begin{array}{l}-0.007 \\
(0.014)\end{array}$ & $\begin{array}{c}-0.009 \\
(0.015)\end{array}$ \\
\hline Charged illegal by 1980 & $\begin{array}{c}0.045^{* * *} \\
(0.011)\end{array}$ & $\begin{array}{c}0.042^{* * *} \\
(0.006)\end{array}$ & $\begin{array}{c}0.043^{* * *} \\
(0.006)\end{array}$ \\
\hline Age first marriage & $\begin{array}{c}-0.035^{* * * *} \\
(0.008)\end{array}$ & $\begin{array}{c}-0.013^{* * * *} \\
(0.002)\end{array}$ & $\begin{array}{c}-0.017 * * * \\
(0.002)\end{array}$ \\
\hline Child before marriage & $\begin{array}{c}0.001 \\
(0.016)\end{array}$ & $\begin{array}{c}0.020 * * * \\
(0.006)\end{array}$ & $\begin{array}{c}0.017 * * * \\
(0.006)\end{array}$ \\
\hline Race: Hispanic & $\begin{array}{l}0.023 * \\
(0.013)\end{array}$ & $\begin{array}{c}-0.001 \\
(0.005)\end{array}$ & $\begin{array}{c}0.003 \\
(0.006)\end{array}$ \\
\hline Race: black & $\begin{array}{c}0.039 * * * \\
(0.008)\end{array}$ & $\begin{array}{c}0.030 * * * \\
(0.005)\end{array}$ & $\begin{array}{c}0.032^{* * *} \\
(0.005)\end{array}$ \\
\hline Constant & $\begin{array}{c}-0.842 * * * \\
(0.221)\end{array}$ & $\begin{array}{c}-0.229 * * * \\
(0.053)\end{array}$ & $\begin{array}{c}-0.322 * * * \\
(0.052)\end{array}$ \\
\hline Region FE & YES & YES & YES \\
\hline Cohort FE & YES & YES & YES \\
\hline Observations & 69,042 & 69,042 & 69,042 \\
\hline Number of respondents & 8,303 & 8,303 & 8,303 \\
\hline
\end{tabular}

Notes: Children conceived during first marriage include only those children who were born during or after the ninth month of marriage. The sample consists of men and women who were married, irrespective of the age at which they first married. Column (1) shows results using dummies for the number of siblings of the respondent as instruments for the respondent's own children conceived during first marriage. Column (2) uses as instruments a dummy indicating whether the respondent has experienced a multiple birth during first marriage. Column (3) presents results using both sets of instruments. *** Significant at the $1 \%$ level, ** Significant at the $5 \%$ level, * Significant at the $10 \%$ level. 
Table 4. - Children Conceived During First Marriage and Risk of Marital Dissolution:

Effect of Children Under 10 and under 6 Years Old

(Dependent Variable: Risk of Marital Dissolution)

\begin{tabular}{|c|c|c|c|c|c|c|}
\hline & $(1)$ & $(2)$ & $(3)$ & $(4)$ & (5) & $(6)$ \\
\hline Number children conceived within marriage under 6 & $\begin{array}{c}-0.300^{* * * *} \\
(0.107)\end{array}$ & & $\begin{array}{c}-0.115 * * * \\
(0.032)\end{array}$ & & $\begin{array}{c}-0.157^{* * *} \\
(0.031)\end{array}$ & \\
\hline Number children conceived within marriage under 10 & & $\begin{array}{c}-0.268 * * * \\
(0.093)\end{array}$ & & $\begin{array}{c}-0.091 * * * \\
(0.025)\end{array}$ & & $\begin{array}{c}-0.125 * * * \\
(0.024)\end{array}$ \\
\hline Gender & $\begin{array}{c}-0.007 \\
(0.008)\end{array}$ & $\begin{array}{l}-0.009 \\
(0.008)\end{array}$ & $\begin{array}{c}-0.007 * \\
(0.004)\end{array}$ & $\begin{array}{c}-0.008^{* *} \\
(0.004)\end{array}$ & $\begin{array}{l}-0.007 \\
(0.004)\end{array}$ & $\begin{array}{c}-0.008^{*} \\
(0.004)\end{array}$ \\
\hline Age & $\begin{array}{c}0.130 * * * \\
(0.038)\end{array}$ & $\begin{array}{c}0.176^{* * *} \\
(0.053)\end{array}$ & $\begin{array}{c}0.053 * * * \\
(0.011)\end{array}$ & $\begin{array}{c}0.063 * * * \\
(0.014)\end{array}$ & $\begin{array}{c}0.070 * * * \\
(0.011)\end{array}$ & $\begin{array}{c}0.084 * * * \\
(0.014)\end{array}$ \\
\hline Age squared & $\begin{array}{c}-0.002^{* * * *} \\
(0.001)\end{array}$ & $\begin{array}{c}-0.002^{* * * *} \\
(0.001)\end{array}$ & $\begin{array}{c}-0.001 * * * \\
(0.0002)\end{array}$ & $\begin{array}{c}-0.001 * * * \\
(0.0002)\end{array}$ & $\begin{array}{c}-0.001 * * * \\
(0.0002)\end{array}$ & $\begin{array}{c}-0.001 * * * \\
(0.0002)\end{array}$ \\
\hline Wife five years older & $\begin{array}{l}-0.024 \\
(0.030)\end{array}$ & $\begin{array}{c}-0.032 \\
(0.031)\end{array}$ & $\begin{array}{c}0.004 \\
(0.012)\end{array}$ & $\begin{array}{c}0.004 \\
(0.012)\end{array}$ & $\begin{array}{l}-0.003 \\
(0.013)\end{array}$ & $\begin{array}{l}-0.004 \\
(0.012)\end{array}$ \\
\hline Husband five years older & $\begin{array}{c}0.018^{*} \\
(0.010)\end{array}$ & $\begin{array}{c}0.013 \\
(0.009)\end{array}$ & $\begin{array}{c}0.014^{* * * *} \\
(0.005)\end{array}$ & $\begin{array}{c}0.013^{* * *} \\
(0.005)\end{array}$ & $\begin{array}{c}0.015^{* * * *} \\
(0.005)\end{array}$ & $\begin{array}{c}0.013 * * \\
(0.005)\end{array}$ \\
\hline Highest education: lowest level & $\begin{array}{c}0.033 * * \\
(0.015)\end{array}$ & $\begin{array}{c}0.055^{* * * *} \\
(0.014)\end{array}$ & $\begin{array}{c}0.037 * * * \\
(0.008)\end{array}$ & $\begin{array}{c}0.041^{* * * *} \\
(0.008)\end{array}$ & $\begin{array}{c}0.037 * * * \\
(0.009)\end{array}$ & $\begin{array}{c}0.044 * * * \\
(0.009)\end{array}$ \\
\hline Highest education: high school level & $\begin{array}{c}0.031^{* * * *} \\
(0.010)\end{array}$ & $\begin{array}{c}0.036 * * * \\
(0.009)\end{array}$ & $\begin{array}{c}0.030 * * * \\
(0.005)\end{array}$ & $\begin{array}{c}0.031 * * * \\
(0.005)\end{array}$ & $\begin{array}{c}0.031^{* * * *} \\
(0.006)\end{array}$ & $\begin{array}{c}0.032 * * * \\
(0.006)\end{array}$ \\
\hline Highest education: college level & $\begin{array}{c}0.008 \\
(0.012)\end{array}$ & $\begin{array}{c}0.015 \\
(0.010)\end{array}$ & $\begin{array}{c}0.020 * * * \\
(0.005)\end{array}$ & $\begin{array}{c}0.022 * * * \\
(0.005)\end{array}$ & $\begin{array}{c}0.018 * * * \\
(0.006)\end{array}$ & $\begin{array}{c}0.021 * * * \\
(0.005)\end{array}$ \\
\hline Highest education spouse: lowest level & $\begin{array}{c}0.016 \\
(0.012)\end{array}$ & $\begin{array}{c}0.023 * * \\
(0.012)\end{array}$ & $\begin{array}{c}0.024 * * * \\
(0.007)\end{array}$ & $\begin{array}{c}0.025^{* * * *} \\
(0.007)\end{array}$ & $\begin{array}{c}0.023 * * * \\
(0.008)\end{array}$ & $\begin{array}{c}0.025 * * * \\
(0.008)\end{array}$ \\
\hline Highest education spouse: high school level & $\begin{array}{l}-0.007 \\
(0.011)\end{array}$ & $\begin{array}{l}-0.001 \\
(0.009)\end{array}$ & $\begin{array}{c}0.006 \\
(0.005)\end{array}$ & $\begin{array}{c}0.007 \\
(0.005)\end{array}$ & $\begin{array}{c}0.003 \\
(0.006)\end{array}$ & $\begin{array}{c}0.005 \\
(0.006)\end{array}$ \\
\hline Highest education spouse: college level & $\begin{array}{l}-0.009 \\
(0.011)\end{array}$ & $\begin{array}{l}-0.005 \\
(0.009)\end{array}$ & $\begin{array}{c}0.003 \\
(0.005)\end{array}$ & $\begin{array}{c}0.005 \\
(0.005)\end{array}$ & $\begin{array}{l}0.0004 \\
(0.006)\end{array}$ & $\begin{array}{c}0.002 \\
(0.005)\end{array}$ \\
\hline Father in household in 1979 & $\begin{array}{l}-0.017^{*} \\
(0.009)\end{array}$ & $\begin{array}{c}-0.020 * * \\
(0.009)\end{array}$ & $\begin{array}{c}-0.018 * * * \\
(0.004)\end{array}$ & $\begin{array}{c}-0.019 * * * \\
(0.004)\end{array}$ & $\begin{array}{c}-0.018 * * * \\
(0.005)\end{array}$ & $\begin{array}{c}-0.019 * * * \\
(0.005)\end{array}$ \\
\hline Without father figure in 1979 & $\begin{array}{l}-0.018 \\
(0.034)\end{array}$ & $\begin{array}{c}-0.024 \\
(0.034)\end{array}$ & $\begin{array}{l}-0.015 \\
(0.017)\end{array}$ & $\begin{array}{l}-0.016 \\
(0.017)\end{array}$ & $\begin{array}{l}-0.016 \\
(0.019)\end{array}$ & $\begin{array}{l}-0.018 \\
(0.019)\end{array}$ \\
\hline Charged illegal by 1980 & $\begin{array}{c}0.030 * * \\
(0.015)\end{array}$ & $\begin{array}{c}0.033 * * \\
(0.014)\end{array}$ & $\begin{array}{c}0.029 * * * \\
(0.007)\end{array}$ & $\begin{array}{c}0.031 * * * \\
(0.007)\end{array}$ & $\begin{array}{c}0.028 * * * \\
(0.008)\end{array}$ & $\begin{array}{c}0.031 * * * \\
(0.008)\end{array}$ \\
\hline Age first marriage & $\begin{array}{c}-0.011 * * * \\
(0.002)\end{array}$ & $\begin{array}{c}-0.019 * * * \\
(0.005)\end{array}$ & $\begin{array}{c}-0.006 * * * \\
(0.001)\end{array}$ & $\begin{array}{c}-0.008 * * * \\
(0.001)\end{array}$ & $\begin{array}{c}-0.007 * * * \\
(0.001)\end{array}$ & $\begin{array}{c}-0.010 * * * \\
(0.001)\end{array}$ \\
\hline Child before marriage & $\begin{array}{c}0.013 \\
(0.017)\end{array}$ & $\begin{array}{c}0.002 \\
(0.019)\end{array}$ & $\begin{array}{c}0.021^{* * *} \\
(0.007)\end{array}$ & $\begin{array}{c}0.019 * * * \\
(0.007)\end{array}$ & $\begin{array}{c}0.017 * * \\
(0.007)\end{array}$ & $\begin{array}{c}0.015^{* *} \\
(0.008)\end{array}$ \\
\hline Race: Hispanic & $\begin{array}{c}0.024 \\
(0.016)\end{array}$ & $\begin{array}{c}0.022 \\
(0.015)\end{array}$ & $\begin{array}{c}0.004 \\
(0.006)\end{array}$ & $\begin{array}{c}0.003 \\
(0.006)\end{array}$ & $\begin{array}{c}0.008 \\
(0.007)\end{array}$ & $\begin{array}{c}0.006 \\
(0.007)\end{array}$ \\
\hline Race: black & $\begin{array}{c}0.041 * * * \\
(0.011)\end{array}$ & $\begin{array}{c}0.039 * * * \\
(0.011)\end{array}$ & $\begin{array}{c}0.033^{* * *} \\
(0.006)\end{array}$ & $\begin{array}{c}0.033 * * * \\
(0.005)\end{array}$ & $\begin{array}{c}0.034 * * * \\
(0.006)\end{array}$ & $\begin{array}{c}0.033^{* * *} \\
(0.006)\end{array}$ \\
\hline Constant & $\begin{array}{c}-1.609 * * * \\
(0.511)\end{array}$ & $\begin{array}{c}-2.272 * * * \\
(0.730)\end{array}$ & $\begin{array}{c}-0.615 * * * \\
(0.151)\end{array}$ & $\begin{array}{c}-0.766 * * * \\
(0.190)\end{array}$ & $\begin{array}{c}-0.833^{* * *} \\
(0.147)\end{array}$ & $\begin{array}{c}-1.049 * * * \\
(0.186)\end{array}$ \\
\hline Region FE & YES & YES & YES & YES & YES & YES \\
\hline Cohort FE & YES & YES & YES & YES & YES & YES \\
\hline Observations & 45,632 & 45,632 & 45,632 & 45,632 & 45,632 & 45,632 \\
\hline Number of respondents & 5,622 & 5,622 & 5,622 & 5,622 & 5,622 & 5,622 \\
\hline
\end{tabular}

Notes: Children conceived during first marriage under 6 and 10 include only those children who were born during or after the ninth month of marriage and who are under 6 and 10 years old, respectively. The sample consists of men and women who were at least 21 years old when they first married. Columns (1) and (2) show results using dummies for the number of siblings of the respondent as instruments for the respondent's own children during first marriage. Columns (3) and (4) use as instruments a dummy indicating whether the respondent has experienced a multiple birth during first marriage. Columns (5) and (6) present results using both sets of instruments. *** Significant at the $1 \%$ level, ** Significant at the $5 \%$ level, * Significant at the $10 \%$ level. 
Table 5. - Children Conceived and Risk of Marital Dissolution:

Sample Including All Children Conceived

(Dependent Variable: Risk of Marital Dissolution)

\begin{tabular}{|c|c|c|c|}
\hline & $(1)$ & $(2)$ & (3) \\
\hline Number children of the respondent & $\begin{array}{c}-0.134^{* * *} \\
(0.035)\end{array}$ & $\begin{array}{c}-0.050^{* * *} \\
(0.013)\end{array}$ & $\begin{array}{c}-0.065^{* * *} \\
(0.012)\end{array}$ \\
\hline Gender & $\begin{array}{c}-0.011^{* *} \\
(0.005)\end{array}$ & $\begin{array}{c}-0.009 * * \\
(0.004)\end{array}$ & $\begin{array}{c}-0.009 * * \\
(0.004)\end{array}$ \\
\hline Age & $\begin{array}{c}0.076^{* * *} \\
(0.015)\end{array}$ & $\begin{array}{c}0.034^{* * *} \\
(0.006)\end{array}$ & $\begin{array}{c}0.041^{* * *} \\
(0.005)\end{array}$ \\
\hline Age squared & $\begin{array}{c}-0.001^{* * *} \\
(0.0002)\end{array}$ & $\begin{array}{c}-0.0004^{* * *} \\
(0.0001)\end{array}$ & $\begin{array}{c}-0.0005^{* * *} \\
(0.0001)\end{array}$ \\
\hline Wife five years older & $\begin{array}{c}-0.013 \\
(0.018)\end{array}$ & $\begin{array}{c}0.010 \\
(0.011)\end{array}$ & $\begin{array}{c}0.006 \\
(0.011)\end{array}$ \\
\hline Husband five years older & $\begin{array}{c}0.014 * * \\
(0.006)\end{array}$ & $\begin{array}{c}0.014^{* * *} \\
(0.005)\end{array}$ & $\begin{array}{c}0.014^{* * *} \\
(0.005)\end{array}$ \\
\hline Highest education: lowest level & $\begin{array}{c}0.082 * * * \\
(0.014)\end{array}$ & $\begin{array}{c}0.052^{* * *} \\
(0.008)\end{array}$ & $\begin{array}{c}0.057 * * * \\
(0.008)\end{array}$ \\
\hline Highest education: high school level & $\begin{array}{c}0.052 * * * \\
(0.008)\end{array}$ & $\begin{array}{c}0.037 * * * \\
(0.005)\end{array}$ & $\begin{array}{c}0.039 * * * \\
(0.005)\end{array}$ \\
\hline Highest education: college level & $\begin{array}{c}0.033^{* * *} \\
(0.006)\end{array}$ & $\begin{array}{c}0.026^{* * *} \\
(0.005)\end{array}$ & $\begin{array}{c}0.027 * * * \\
(0.005)\end{array}$ \\
\hline Highest education spouse: lowest level & $\begin{array}{c}0.040^{* * * *} \\
(0.010)\end{array}$ & $\begin{array}{c}0.032 * * * \\
(0.007)\end{array}$ & $\begin{array}{c}0.034 * * * \\
(0.007)\end{array}$ \\
\hline Highest education spouse: high school level & $\begin{array}{c}0.010 \\
(0.006)\end{array}$ & $\begin{array}{c}0.012 * * \\
(0.005)\end{array}$ & $\begin{array}{c}0.011^{* *} \\
(0.005)\end{array}$ \\
\hline Highest education spouse: college level & $\begin{array}{c}0.007 \\
(0.006)\end{array}$ & $\begin{array}{c}0.009 * * \\
(0.005)\end{array}$ & $\begin{array}{l}0.009 * \\
(0.005)\end{array}$ \\
\hline Father in household in 1979 & $\begin{array}{c}-0.028 * * * \\
(0.006)\end{array}$ & $\begin{array}{c}-0.023 * * * \\
(0.004)\end{array}$ & $\begin{array}{c}-0.023 * * * \\
(0.004)\end{array}$ \\
\hline Without father figure in 1979 & $\begin{array}{l}-0.017 \\
(0.022)\end{array}$ & $\begin{array}{l}-0.015 \\
(0.017)\end{array}$ & $\begin{array}{l}-0.015 \\
(0.017)\end{array}$ \\
\hline Charged illegal by 1980 & $\begin{array}{c}0.042 * * * \\
(0.009)\end{array}$ & $\begin{array}{c}0.035^{* * *} \\
(0.007)\end{array}$ & $\begin{array}{c}0.036 * * * \\
(0.007)\end{array}$ \\
\hline Age first marriage & $\begin{array}{c}-0.020^{* * *} \\
(0.004)\end{array}$ & $\begin{array}{c}-0.009 * * * \\
(0.002)\end{array}$ & $\begin{array}{c}-0.011 * * * \\
(0.001)\end{array}$ \\
\hline Child before marriage & $\begin{array}{c}0.212^{* * *} \\
(0.045)\end{array}$ & $\begin{array}{c}0.098 * * * \\
(0.018)\end{array}$ & $\begin{array}{c}0.118^{* * *} \\
(0.017)\end{array}$ \\
\hline Race: Hispanic & $\begin{array}{c}0.014 \\
(0.009)\end{array}$ & $\begin{array}{c}0.001 \\
(0.006)\end{array}$ & $\begin{array}{c}0.003 \\
(0.006)\end{array}$ \\
\hline Race: black & $\begin{array}{c}0.058 * * * \\
(0.008)\end{array}$ & $\begin{array}{c}0.042^{* * *} \\
(0.005)\end{array}$ & $\begin{array}{c}0.044^{* * *} \\
(0.006)\end{array}$ \\
\hline Constant & $\begin{array}{c}-0.795 * * * \\
(0.173)\end{array}$ & $\begin{array}{c}-0.323 * * * \\
(0.068)\end{array}$ & $\begin{array}{c}-0.400 * * * \\
(0.064)\end{array}$ \\
\hline Region FE & YES & YES & YES \\
\hline Cohort FE & YES & YES & YES \\
\hline Observations & 45,632 & 45,632 & 45,632 \\
\hline Number of respondents & 5,622 & 5,622 & 5,622 \\
\hline
\end{tabular}

Notes: Children of the respondents include also children conceived before the first marriage (see Section 4 for more details). The sample consists of men and women who were at least 21 years old when they first married. Column (1) shows results using dummies for the number of siblings of respondent as instruments for the number of children of the respondent. Column (2) uses as instruments a dummy indicating whether the respondent has experienced a multiple birth during the first marriage. Column (3) presents results using both sets of instruments. *** Significant at the $1 \%$ level, ** Significant at the $5 \%$ level, * Significant at the $10 \%$ level. 
Table 6. - Children Conceived Before and During First Marriage and Risk of Marital Dissolution: Children Conceived Before-During Marriage

(Dependent Variable: Risk of Marital Dissolution)

\begin{tabular}{|c|c|c|c|}
\hline & $(1)$ & $(2)$ & (3) \\
\hline Number children conceived within marriage & $\begin{array}{c}-0.336^{* * *} \\
(0.080)\end{array}$ & $\begin{array}{c}-0.159 * * * \\
(0.026)\end{array}$ & $\begin{array}{c}-0.193 * * * \\
(0.027)\end{array}$ \\
\hline Number children conceived before marriage & $\begin{array}{c}0.080 * * * \\
(0.030)\end{array}$ & $\begin{array}{c}0.122 * * * \\
(0.020)\end{array}$ & $\begin{array}{c}0.100^{* * *} \\
(0.020)\end{array}$ \\
\hline Gender & $\begin{array}{c}0.001 \\
(0.009)\end{array}$ & $\begin{array}{c}0.004 \\
(0.005)\end{array}$ & $\begin{array}{c}0.002 \\
(0.006)\end{array}$ \\
\hline Age & $\begin{array}{c}0.170 * * * \\
(0.035)\end{array}$ & $\begin{array}{c}0.085^{* * *} * \\
(0.011)\end{array}$ & $\begin{array}{c}0.102 * * * \\
(0.012)\end{array}$ \\
\hline Age squared & $\begin{array}{c}-0.002^{* * *} \\
(0.000)\end{array}$ & $\begin{array}{c}-0.001^{* * *} \\
(0.000)\end{array}$ & $\begin{array}{c}-0.001 * * * \\
(0.000)\end{array}$ \\
\hline Wife five years older & $\begin{array}{l}-0.050 \\
(0.032)\end{array}$ & $\begin{array}{c}0.001 \\
(0.015)\end{array}$ & $\begin{array}{c}-0.011 \\
(0.016)\end{array}$ \\
\hline Husband five years older & $\begin{array}{c}0.010 \\
(0.010)\end{array}$ & $\begin{array}{c}0.013 * * \\
(0.006)\end{array}$ & $\begin{array}{l}0.012^{*} \\
(0.007)\end{array}$ \\
\hline Highest education: lowest level & $\begin{array}{c}0.054^{* *} \\
(0.025)\end{array}$ & $\begin{array}{c}-0.007 \\
(0.014)\end{array}$ & $\begin{array}{c}0.010 \\
(0.015)\end{array}$ \\
\hline Highest education: high school level & $\begin{array}{c}0.033^{* *} \\
(0.013)\end{array}$ & $\begin{array}{c}0.006 \\
(0.008)\end{array}$ & $\begin{array}{c}0.014 \\
(0.009)\end{array}$ \\
\hline Highest education: college level & $\begin{array}{l}0.017 * \\
(0.009)\end{array}$ & $\begin{array}{c}0.011 \\
(0.006)\end{array}$ & $\begin{array}{c}0.014^{* *} \\
(0.007)\end{array}$ \\
\hline Highest education spouse: lowest level & $\begin{array}{c}0.006 \\
(0.014)\end{array}$ & $\begin{array}{c}-0.006 \\
(0.010)\end{array}$ & $\begin{array}{l}-0.000 \\
(0.010)\end{array}$ \\
\hline Highest education spouse: high school level & $\begin{array}{l}-0.015 \\
(0.010)\end{array}$ & $\begin{array}{l}-0.012 * \\
(0.007)\end{array}$ & $\begin{array}{l}-0.011 \\
(0.007)\end{array}$ \\
\hline Highest education spouse: college level & $\begin{array}{c}-0.012 \\
(0.009)\end{array}$ & $\begin{array}{c}-0.006 \\
(0.006)\end{array}$ & $\begin{array}{c}-0.007 \\
(0.006)\end{array}$ \\
\hline Father in household in 1979 & $\begin{array}{c}-0.005 \\
(0.011)\end{array}$ & $\begin{array}{c}-0.003 \\
(0.006)\end{array}$ & $\begin{array}{c}-0.006 \\
(0.007)\end{array}$ \\
\hline Without father figure in 1979 & $\begin{array}{l}-0.048 \\
(0.037)\end{array}$ & $\begin{array}{l}-0.040^{*} \\
(0.022)\end{array}$ & $\begin{array}{l}-0.039 \\
(0.024)\end{array}$ \\
\hline Charged illegal by 1980 & $\begin{array}{c}0.018 \\
(0.016)\end{array}$ & $\begin{array}{l}0.018^{*} \\
(0.009)\end{array}$ & $\begin{array}{l}0.020^{*} \\
(0.010)\end{array}$ \\
\hline Age first marriage & $\begin{array}{c}-0.051^{* * *} \\
(0.010)\end{array}$ & $\begin{array}{c}-0.029 * * * \\
(0.003)\end{array}$ & $\begin{array}{c}-0.033^{* * *} \\
(0.004)\end{array}$ \\
\hline Race: hispanic & $\begin{array}{c}0.018 \\
(0.016)\end{array}$ & $\begin{array}{c}-0.004 \\
(0.008)\end{array}$ & $\begin{array}{c}0.002 \\
(0.009)\end{array}$ \\
\hline Race: black & $\begin{array}{l}-0.023 \\
(0.023)\end{array}$ & $\begin{array}{c}-0.042^{* * *} \\
(0.015)\end{array}$ & $\begin{array}{c}-0.029 * \\
(0.016)\end{array}$ \\
\hline Constant & $\begin{array}{c}-1.692 * * * \\
(0.378)\end{array}$ & $\begin{array}{c}-0.742^{* * *} \\
(0.116)\end{array}$ & $\begin{array}{c}-0.937 * * * \\
(0.121)\end{array}$ \\
\hline Region FE & YES & YES & YES \\
\hline Cohort FE & YES & YES & YES \\
\hline Observations & 45,445 & 45,445 & 45,445 \\
\hline Number of respondents & 5,577 & 5,577 & 5,577 \\
\hline
\end{tabular}

Notes: Children conceived during first marriage include only those children who were born during or after the ninth month of marriage. Children conceived before marriage includes only those children who were born before and during the first eight months of marriage. The sample consists of men and women who were at least 21 years old when they first married. Columns (1), (2) and (3) show results using as instruments for children conceived during first marriage, dummies for the number of siblings of respondent, a dummy indicating whether the respondent has experienced a multiple birth, and both sets of instruments simultaneously, respectively. Columns (1), (2) and (3) show results using as instruments for children conceived before first marriage, dummies indicating whether interviewees had their first sex before 16 years old, between 16 and 18 years old, at more than 18 years old, or had not had sex, by the years 1983-1985, when respondents were between 21 and 28 years old. *** Significant at the $1 \%$ level, ** Significant at the $5 \%$ level, * Significant at the $10 \%$ level. 
Table 7. - Children Conceived During First Marriage and Risk of Marital Dissolution: New Covariates (Dependent Variable: Risk of Marital Dissolution)

\begin{tabular}{|c|c|c|c|c|c|c|}
\hline & $(1)$ & $(2)$ & (3) & (4) & (5) & $(6)$ \\
\hline \multirow[t]{2}{*}{ Children conceived within marriage } & $-0.104 * * *$ & $-0.121 * * *$ & $-0.104 * * *$ & $-0.093 * * *$ & $-0.166 * * *$ & $-0.157 * * *$ \\
\hline & $(0.020)$ & $(0.023)$ & $(0.020)$ & $(0.019)$ & $(0.032)$ & $(0.031)$ \\
\hline \multirow[t]{2}{*}{ Gender } & $-0.008 *$ & -0.006 & $-0.008 *$ & $-0.007^{*}$ & -0.007 & -0.004 \\
\hline & $(0.004)$ & $(0.005)$ & $(0.004)$ & $(0.004)$ & $(0.006)$ & $(0.005)$ \\
\hline \multirow[t]{2}{*}{ Age } & $0.059 * * *$ & $0.068 * * *$ & $0.059 * * *$ & $0.053 * * *$ & $0.097 * * *$ & $0.091 * * *$ \\
\hline & $(0.009)$ & $(0.010)$ & $(0.009)$ & $(0.008)$ & $(0.016)$ & $(0.016)$ \\
\hline \multirow[t]{2}{*}{ Age squared } & $-0.001 * * *$ & $-0.001 * * *$ & $-0.001 * * *$ & $-0.001 * * *$ & $-0.001 * * *$ & $-0.001 * * *$ \\
\hline & $(0.0001)$ & $(0.0001)$ & $(0.0001)$ & $(0.0001)$ & $(0.0002)$ & $(0.0002)$ \\
\hline \multirow[t]{2}{*}{ Wife five years older } & -0.002 & -0.021 & -0.003 & -0.00002 & 0.011 & 0.004 \\
\hline & $(0.012)$ & $(0.014)$ & $(0.012)$ & $(0.012)$ & $(0.016)$ & $(0.016)$ \\
\hline \multirow[t]{2}{*}{ Husband five years older } & $0.013^{* * *}$ & $0.016 * * *$ & $0.014^{* * *}$ & $0.012 * *$ & $0.016 * *$ & $0.016 * *$ \\
\hline & $(0.005)$ & $(0.006)$ & $(0.005)$ & $(0.005)$ & $(0.007)$ & $(0.007)$ \\
\hline \multirow[t]{2}{*}{ Highest education: lowest level } & $0.049 * * *$ & $0.039 * * *$ & $0.048 * * *$ & $0.049 * * *$ & $0.055 * * *$ & $0.048 * * *$ \\
\hline & $(0.008)$ & $(0.009)$ & $(0.009)$ & $(0.008)$ & $(0.011)$ & $(0.011)$ \\
\hline \multirow[t]{2}{*}{ Highest education: high school level } & $0.035^{* * *}$ & $0.029 * * *$ & $0.035^{* * *}$ & $0.033^{* * *}$ & $0.038 * * *$ & $0.031 * * *$ \\
\hline & $(0.005)$ & $(0.006)$ & $(0.005)$ & $(0.005)$ & $(0.007)$ & $(0.007)$ \\
\hline \multirow[t]{2}{*}{ Highest education: college level } & $0.025 * * *$ & $0.019 * * *$ & $0.025 * * *$ & $0.023 * * *$ & $0.031 * * *$ & $0.026 * * *$ \\
\hline & $(0.005)$ & $(0.006)$ & $(0.005)$ & $(0.005)$ & $(0.007)$ & $(0.007)$ \\
\hline \multirow[t]{2}{*}{ Highest education spouse: lowest level } & $0.025 * * *$ & $0.024 * * *$ & $0.023 * * *$ & $0.025 * * *$ & $0.027 * * *$ & $0.020 * *$ \\
\hline & $(0.007)$ & $(0.008)$ & $(0.007)$ & $(0.007)$ & $(0.010)$ & $(0.010)$ \\
\hline \multirow[t]{2}{*}{ Highest education spouse: high school level } & 0.006 & 0.002 & 0.006 & 0.008 & 0.008 & 0.005 \\
\hline & $(0.005)$ & $(0.006)$ & $(0.005)$ & $(0.005)$ & $(0.007)$ & $(0.007)$ \\
\hline \multirow[t]{2}{*}{ Highest education spouse: college level } & 0.004 & -0.003 & 0.004 & 0.005 & 0.008 & 0.007 \\
\hline & $(0.005)$ & $(0.006)$ & $(0.005)$ & $(0.005)$ & $(0.007)$ & $(0.007)$ \\
\hline \multirow[t]{2}{*}{ Father in household in 1979} & $-0.020 * * *$ & $-0.016^{* * *}$ & $-0.020 * * *$ & $-0.018 * * *$ & $-0.021 * * *$ & $-0.017 * * *$ \\
\hline & $(0.005)$ & $(0.005)$ & $(0.005)$ & $(0.005)$ & $(0.006)$ & $(0.006)$ \\
\hline \multirow[t]{2}{*}{ Without father figure in 1979} & -0.018 & -0.029 & -0.018 & -0.012 & -0.029 & -0.023 \\
\hline & $(0.019)$ & $(0.020)$ & $(0.018)$ & $(0.019)$ & $(0.025)$ & $(0.026)$ \\
\hline Charged illegal by 1980 & $0.033 * * *$ & $0.035 * * *$ & $0.033 * * *$ & $0.033 * * *$ & $0.029 * * *$ & $0.030 * * *$ \\
\hline & $(0.007)$ & $(0.008)$ & $(0.007)$ & $(0.007)$ & $(0.010)$ & $(0.010)$ \\
\hline Age first marriage & $-0.017 * * *$ & $-0.020 * * *$ & $-0.017 * * *$ & $-0.015^{* * *}$ & $-0.032 * * *$ & $-0.030 * * *$ \\
\hline & $(0.002)$ & $(0.003)$ & $(0.003)$ & $(0.002)$ & $(0.005)$ & $(0.005)$ \\
\hline Child before marriage & $0.018^{* *}$ & 0.007 & $0.019 * * *$ & $0.016^{* *}$ & $0.016^{*}$ & 0.013 \\
\hline & $(0.007)$ & $(0.008)$ & $(0.007)$ & $(0.007)$ & $(0.010)$ & $(0.010)$ \\
\hline Race: Hispanic & 0.006 & 0.008 & 0.008 & 0.007 & 0.009 & 0.009 \\
\hline & $(0.007)$ & $(0.007)$ & $(0.007)$ & $(0.006)$ & $(0.009)$ & $(0.009)$ \\
\hline Race: black & $0.035^{* * *}$ & $0.026 * * *$ & $0.034 * * *$ & $0.038 * * *$ & $0.036 * * *$ & $0.037 * * *$ \\
\hline & $(0.006)$ & $(0.007)$ & $(0.006)$ & $(0.006)$ & $(0.008)$ & $(0.008)$ \\
\hline Family income indicator & & $-0.054 * * *$ & & & & $-0.056 * * *$ \\
\hline & & $(0.011)$ & & & & $(0.012)$ \\
\hline Family income indicator squared & & $0.009 * * *$ & & & & $0.009 * * *$ \\
\hline & & $(0.002)$ & & & & $(0.002)$ \\
\hline Religion raised: protestant & & & -0.007 & & & -0.013 \\
\hline & & & $(0.011)$ & & & $(0.015)$ \\
\hline Religion raised: roman catholic & & & -0.007 & & & -0.009 \\
\hline & & & $(0.012)$ & & & $(0.016)$ \\
\hline Religion raised: jewish & & & -0.001 & & & -0.012 \\
\hline & & & $(0.021)$ & & & $(0.028)$ \\
\hline Religion raised: other religion & & & -0.004 & & & -0.005 \\
\hline & & & $(0.013)$ & & & $(0.016)$ \\
\hline Living urban & & & & 0.002 & & 0.005 \\
\hline & & & & $(0.003)$ & & $(0.005)$ \\
\hline Employed & & & & & $-0.033 * * *$ & $-0.032 * * *$ \\
\hline & & & & & $(0.008)$ & $(0.008)$ \\
\hline Spouse employed & & & & & $-0.037 * * *$ & $-0.034 * * *$ \\
\hline & & & & & $(0.009)$ & $(0.009)$ \\
\hline Constant & $-0.572 * * *$ & $-0.634 * * *$ & $-0.560 * * *$ & $-0.514 * * *$ & $-0.815^{* * *}$ & $-0.768 * * *$ \\
\hline & $(0.092)$ & $(0.105)$ & $(0.096)$ & $(0.088)$ & $(0.145)$ & $(0.154)$ \\
\hline Region FE & YES & YES & YES & YES & YES & YES \\
\hline Cohort FE & YES & YES & YES & YES & YES & YES \\
\hline Observations & 45,632 & 39,764 & 45,535 & 43,491 & 31,303 & 29,937 \\
\hline Number of respondents & 5,622 & 5,395 & 5,604 & 5,404 & 5,190 & 4,950 \\
\hline
\end{tabular}

Notes: Children conceived during first marriage include only those children who were born during or after the ninth month of marriage. The sample consists of men and women who were at least 21 years old when they first married. All Columns show results using as instruments dummies for the number of siblings of respondent and a dummy indicating whether the respondent has experienced a multiple birth, simultaneously. Column (1) includes our baseline estimates using these instruments (Table 2, Column (3)). Columns (2), (3), (4) and (5) incorporate controls for the family income and its square, the religion under which the interviewee were raised, whether the interviewee's current residence is urban or rural, and whether the interviewee and his/her 
spouse are employed, respectively. Column (6) includes all controls at the same time. *** Significant at the $1 \%$ level, ** Significant at the 5\% level, * Significant at the $10 \%$ level. 
Table 8. - Children Conceived During First Marriage and Risk of Marital Dissolution: Analysis by Educational Level: Instrumental Variables (Dependent Variable: Risk of Marital Dissolution)

\begin{tabular}{|c|c|c|c|}
\hline & $(1)$ & $(2)$ & $(3)$ \\
\hline Children conceived within marriage & $\begin{array}{c}-0.314 \\
(0.208)\end{array}$ & $\begin{array}{c}-0.091 * * * \\
(0.033)\end{array}$ & $\begin{array}{c}-0.105 * * * \\
(0.023)\end{array}$ \\
\hline Gender & $\begin{array}{c}-0.003 \\
(0.042)\end{array}$ & $\begin{array}{c}-0.002 \\
(0.007)\end{array}$ & $\begin{array}{c}-0.009 * \\
(0.005)\end{array}$ \\
\hline Age & $\begin{array}{l}0.134^{*} \\
(0.072)\end{array}$ & $\begin{array}{c}0.054 * * * \\
(0.014)\end{array}$ & $\begin{array}{c}0.061^{* * *} \\
(0.011)\end{array}$ \\
\hline Age squared & $\begin{array}{c}-0.002^{*} \\
(0.001)\end{array}$ & $\begin{array}{c}-0.001 * * * \\
(0.0002)\end{array}$ & $\begin{array}{c}-0.001 * * * \\
(0.0001)\end{array}$ \\
\hline Wife five years older & $\begin{array}{c}-0.075 \\
(0.103)\end{array}$ & $\begin{array}{c}0.006 \\
(0.018)\end{array}$ & $\begin{array}{l}-0.013 \\
(0.016)\end{array}$ \\
\hline Husband five years older & $\begin{array}{c}0.059 * \\
(0.033)\end{array}$ & $\begin{array}{c}0.005 \\
(0.009)\end{array}$ & $\begin{array}{c}0.018 * * * \\
(0.007)\end{array}$ \\
\hline Father in household in 1979 & $\begin{array}{c}-0.059 * * * \\
(0.023)\end{array}$ & $\begin{array}{c}-0.028^{* * *} \\
(0.008)\end{array}$ & $\begin{array}{l}-0.007 \\
(0.006)\end{array}$ \\
\hline Without father figure in 1979 & $\begin{array}{l}-0.005 \\
(0.079)\end{array}$ & $\begin{array}{l}-0.033 \\
(0.027)\end{array}$ & $\begin{array}{c}0.006 \\
(0.031)\end{array}$ \\
\hline Charged illegal by 1980 & $\begin{array}{c}0.040 \\
(0.032)\end{array}$ & $\begin{array}{c}0.032 * * * \\
(0.011)\end{array}$ & $\begin{array}{c}0.020^{*} \\
(0.012)\end{array}$ \\
\hline Age first marriage & $\begin{array}{c}-0.041^{*} \\
(0.022)\end{array}$ & $\begin{array}{c}-0.015^{* * *} \\
(0.004)\end{array}$ & $\begin{array}{c}-0.017 * * * \\
(0.003)\end{array}$ \\
\hline Child before marriage & $\begin{array}{l}-0.068 \\
(0.053)\end{array}$ & $\begin{array}{c}0.027 * * \\
(0.011)\end{array}$ & $\begin{array}{c}0.023 * * \\
(0.010)\end{array}$ \\
\hline Race: hispanic & $\begin{array}{c}0.051 \\
(0.061)\end{array}$ & $\begin{array}{c}0.007 \\
(0.011)\end{array}$ & $\begin{array}{l}0.015^{*} \\
(0.008)\end{array}$ \\
\hline Race: black & $\begin{array}{c}0.082 * * \\
(0.034)\end{array}$ & $\begin{array}{c}0.030^{* * *} \\
(0.010)\end{array}$ & $\begin{array}{c}0.031^{* * *} \\
(0.007)\end{array}$ \\
\hline Same education & $\begin{array}{c}0.041 \\
(0.048)\end{array}$ & $\begin{array}{l}-0.005 \\
(0.007)\end{array}$ & $\begin{array}{c}-0.014 * * * \\
(0.005)\end{array}$ \\
\hline Respondent more educated than spouse & & $\begin{array}{c}0.020^{*} \\
(0.010)\end{array}$ & \\
\hline Constant & $\begin{array}{l}-1.197 \\
(0.746)\end{array}$ & $\begin{array}{c}-0.448 * * * \\
(0.143)\end{array}$ & $\begin{array}{c}-0.604 * * * \\
(0.129)\end{array}$ \\
\hline Region FE & YES & YES & YES \\
\hline Cohort FE & YES & YES & YES \\
\hline Observations & 3,391 & 16,860 & 25,381 \\
\hline Number of respondents & 576 & 2,394 & 2,945 \\
\hline
\end{tabular}

Notes: Children conceived during first marriage include only those children who were born during or after the ninth month of marriage. The sample consists of men and women who were at least 21 years old when they first married. All Columns show results using as instruments dummies for the number of siblings of respondent and a dummy indicating whether the respondent has experienced a multiple birth, simultaneously. In addition, Column (1) shows results for the less educated interviewees, Column (2) shows results for the interviewees with an intermediate level of education, and Column (3) shows results for the interviewees with the highest level of education. *** Significant at the $1 \%$ level, ** Significant at the 5\% level, * Significant at the $10 \%$ level. 
Table 9. - Children Conceived During First Marriage and Risk of Marital Dissolution: Survival Analysis

(Dependent Variable: Risk of Marital Dissolution)

\begin{tabular}{|c|c|c|c|}
\hline & $(1)$ & $(2)$ & (3) \\
\hline Children conceived within marriage & $\begin{array}{c}-0.229 * * * \\
(0.031)\end{array}$ & $\begin{array}{c}-0.236 * * * \\
(0.032)\end{array}$ & $\begin{array}{c}-0.288 * * * \\
(0.035)\end{array}$ \\
\hline Gender & $\begin{array}{l}-0.085^{*} \\
(0.046)\end{array}$ & $\begin{array}{l}-0.087^{*} \\
(0.048)\end{array}$ & $\begin{array}{c}-0.111^{* *} \\
(0.056)\end{array}$ \\
\hline Age & $\begin{array}{l}0.066^{*} \\
(0.034)\end{array}$ & $\begin{array}{l}0.069 * * \\
(0.035)\end{array}$ & $\begin{array}{c}0.196^{* * *} \\
(0.049)\end{array}$ \\
\hline Age squared & $\begin{array}{l}-0.001^{* *} \\
(0.0005)\end{array}$ & $\begin{array}{l}-0.001 * * \\
(0.0005)\end{array}$ & $\begin{array}{c}-0.002 * * * \\
(0.001)\end{array}$ \\
\hline Wife five years older & $\begin{array}{l}0.229 * * \\
(0.107)\end{array}$ & $\begin{array}{c}0.237 * * \\
(0.112)\end{array}$ & $\begin{array}{l}0.287 * * \\
(0.132)\end{array}$ \\
\hline Husband five years older & $\begin{array}{c}0.206 * * * \\
(0.055)\end{array}$ & $\begin{array}{c}0.216^{* * *} \\
(0.056)\end{array}$ & $\begin{array}{c}0.248 * * * \\
(0.067)\end{array}$ \\
\hline Highest education: lowest level & $\begin{array}{c}0.582 * * * \\
(0.101)\end{array}$ & $\begin{array}{c}0.594 * * * \\
(0.104)\end{array}$ & $\begin{array}{c}0.680^{* * *} \\
(0.121)\end{array}$ \\
\hline Highest education: high school level & $\begin{array}{c}0.516 * * * \\
(0.074)\end{array}$ & $\begin{array}{c}0.526 * * * \\
(0.076)\end{array}$ & $\begin{array}{c}0.609 * * * \\
(0.089)\end{array}$ \\
\hline Highest education: college level & $\begin{array}{c}0.422 * * * \\
(0.075)\end{array}$ & $\begin{array}{c}0.430 * * * \\
(0.076)\end{array}$ & $\begin{array}{c}0.508 * * * \\
(0.088)\end{array}$ \\
\hline Highest education spouse: lowest level & $\begin{array}{c}0.384 * * * \\
(0.097)\end{array}$ & $\begin{array}{c}0.397 * * * \\
(0.100)\end{array}$ & $\begin{array}{c}0.468 * * * \\
(0.112)\end{array}$ \\
\hline Highest education spouse: high school level & $\begin{array}{c}0.256 * * * \\
(0.074)\end{array}$ & $\begin{array}{c}0.262 * * * \\
(0.075)\end{array}$ & $\begin{array}{c}0.296 * * * \\
(0.085)\end{array}$ \\
\hline Highest education spouse: college level & $\begin{array}{c}0.239 * * * \\
(0.076)\end{array}$ & $\begin{array}{c}0.244^{* * *} \\
(0.077)\end{array}$ & $\begin{array}{c}0.271^{* * *} \\
(0.085)\end{array}$ \\
\hline Father in household in 1979 & $\begin{array}{c}-0.276^{* * * *} \\
(0.049)\end{array}$ & $\begin{array}{c}-0.285^{* * * *} \\
(0.051)\end{array}$ & $\begin{array}{c}-0.324 * * * \\
(0.061)\end{array}$ \\
\hline Without father figure in 1979 & $\begin{array}{l}-0.237 \\
(0.181)\end{array}$ & $\begin{array}{l}-0.241 \\
(0.189)\end{array}$ & $\begin{array}{l}-0.238 \\
(0.226)\end{array}$ \\
\hline Charged illegal by 1980 & $\begin{array}{c}0.341 * * * \\
(0.072)\end{array}$ & $\begin{array}{c}0.353^{* * *} \\
(0.075)\end{array}$ & $\begin{array}{c}0.414^{* * *} \\
(0.092)\end{array}$ \\
\hline Age first marriage & $\begin{array}{l}-0.001 \\
(0.007)\end{array}$ & $\begin{array}{l}-0.002 \\
(0.008)\end{array}$ & $\begin{array}{c}-0.048 * * * \\
(0.014)\end{array}$ \\
\hline Child before marriage & $\begin{array}{c}0.233 * * * \\
(0.062)\end{array}$ & $\begin{array}{c}0.245^{* * *} \\
(0.064)\end{array}$ & $\begin{array}{c}0.316 * * * \\
(0.076)\end{array}$ \\
\hline Race: hispanic & $\begin{array}{l}-0.027 \\
(0.069)\end{array}$ & $\begin{array}{l}-0.028 \\
(0.071)\end{array}$ & $\begin{array}{l}-0.045 \\
(0.081)\end{array}$ \\
\hline Race: black & $\begin{array}{c}0.343 * * * \\
(0.062)\end{array}$ & $\begin{array}{c}0.355^{* * *} \\
(0.064)\end{array}$ & $\begin{array}{c}0.436 * * * \\
(0.076)\end{array}$ \\
\hline Constant & $\begin{array}{c}-4.133^{* * *} \\
(0.553)\end{array}$ & $\begin{array}{l}-4.140^{* * *} \\
(0.571)\end{array}$ & $\begin{array}{c}-5.849 * * * \\
(0.744)\end{array}$ \\
\hline Region FE & YES & YES & YES \\
\hline Cohort FE & YES & YES & YES \\
\hline $\begin{array}{l}\text { Observations } \\
\text { Number of respondents }\end{array}$ & 45,632 & 45,632 & $\begin{array}{c}45,632 \\
5,622\end{array}$ \\
\hline
\end{tabular}

Notes: Children conceived during first marriage include only those children who were born during or after the ninth month of marriage. The sample consists of men and women who were at least 21 years old when they first married. Columns (1), (2) and (3) display results from using the complementary log-log, logistic and log-log with unobserved heterogeneity models, respectively. *** Significant at the $1 \%$ level, ** Significant at the $5 \%$ level, * Significant at the $10 \%$ level. 


\section{APPENDIX A}

Table A. - Instrumental Variables, First Step of Results Shown in Table 2 (Dependent Variable: Number of Children Conceived During First Marriage)

\begin{tabular}{|c|c|c|c|}
\hline & (1) & (2) & (3) \\
\hline \multirow[t]{2}{*}{ One sibling } & 0.013 & & 0.014 \\
\hline & $(0.049)$ & & $(0.036)$ \\
\hline \multirow[t]{2}{*}{ Two siblings } & 0.055 & & $0.064 *$ \\
\hline & $(0.048)$ & & $(0.035)$ \\
\hline \multirow[t]{2}{*}{ Three siblings } & 0.074 & & $0.081 * *$ \\
\hline & $(0.048)$ & & $(0.036)$ \\
\hline \multirow[t]{2}{*}{ Four or more siblings } & $0.132 * * *$ & & $0.145 * * *$ \\
\hline & $(0.047)$ & & $(0.035)$ \\
\hline \multirow[t]{2}{*}{ Multiple birth } & & $0.582 * * *$ & $0.570 * * *$ \\
\hline & & $(0.035)$ & $(0.037)$ \\
\hline \multirow[t]{2}{*}{ Gender } & 0.020 & $0.025 * *$ & $0.026 * *$ \\
\hline & $(0.016)$ & $(0.011)$ & $(0.012)$ \\
\hline \multirow[t]{2}{*}{ Age } & $0.433 * * *$ & $0.423 * * *$ & $0.425 * * *$ \\
\hline & $(0.004)$ & $(0.004)$ & $(0.004)$ \\
\hline \multirow[t]{2}{*}{ Age squared } & $-0.005 * * *$ & $-0.005 * * *$ & $-0.005 * * *$ \\
\hline & $(0.00005)$ & $(0.00006)$ & $(0.00006)$ \\
\hline \multirow[t]{2}{*}{ Wife five years older } & $-0.308 * * *$ & $-0.306 * * *$ & $-0.301 * * *$ \\
\hline & $(0.038)$ & $(0.028)$ & $(0.029)$ \\
\hline \multirow[t]{2}{*}{ Husband five years older } & -0.025 & -0.017 & -0.020 \\
\hline & $(0.019)$ & $(0.014)$ & $(0.014)$ \\
\hline \multirow[t]{2}{*}{ Highest education: lowest level } & $0.123 * * *$ & $0.065 * * *$ & $0.054 * *$ \\
\hline & $(0.029)$ & $(0.023)$ & $(0.024)$ \\
\hline \multirow[t]{2}{*}{ Highest education: high school level } & $0.041^{* *}$ & 0.018 & 0.010 \\
\hline & $(0.019)$ & $(0.015)$ & $(0.016)$ \\
\hline \multirow[t]{2}{*}{ Highest education: college level } & -0.021 & -0.011 & -0.018 \\
\hline & $(0.017)$ & $(0.014)$ & $(0.014)$ \\
\hline \multirow[t]{2}{*}{ Highest education spouse: lowest level } & 0.011 & 0.002 & -0.006 \\
\hline & $(0.024)$ & $(0.021)$ & $(0.021)$ \\
\hline \multirow[t]{2}{*}{ Highest education spouse: high school level } & $-0.056 * * *$ & $-0.069 * * *$ & $-0.071 * * *$ \\
\hline & $(0.017)$ & $(0.014)$ & $(0.015)$ \\
\hline \multirow[t]{2}{*}{ Highest education spouse: college level } & $-0.061 * * *$ & $-0.067 * * *$ & $-0.069 * * *$ \\
\hline & $(0.016)$ & $(0.014)$ & $(0.014)$ \\
\hline \multirow[t]{2}{*}{ Father in household in 1979} & $0.031^{*}$ & $0.029 * *$ & $0.030 * *$ \\
\hline & $(0.017)$ & $(0.012)$ & $(0.013)$ \\
\hline \multirow[t]{2}{*}{ Without father figure in 1979} & -0.067 & -0.077 & -0.075 \\
\hline & $(0.069)$ & $(0.050)$ & $(0.052)$ \\
\hline \multirow[t]{2}{*}{ Charged illegal by 1980} & -0.048 & $-0.035^{*}$ & -0.037 \\
\hline & $(0.028)$ & $(0.020)$ & $(0.021)$ \\
\hline \multirow[t]{2}{*}{ Age first marriage } & $-0.121 * * *$ & $-0.124 * * *$ & $-0.123 * * *$ \\
\hline & $(0.002)$ & $(0.001)$ & $(0.001)$ \\
\hline \multirow[t]{2}{*}{ Child before marriage } & $-0.203 * * *$ & $-0.196 * * *$ & $-0.206 * * *$ \\
\hline & $(0.023)$ & $(0.016)$ & $(0.017)$ \\
\hline Race: hispanic & $0.102 * * *$ & $0.127 * * *$ & $0.107 * * *$ \\
\hline & $(0.023)$ & $(0.016)$ & $(0.017)$ \\
\hline Race: black & $-0.057 * *$ & $-0.049 * * *$ & $-0.070 * * *$ \\
\hline & $(0.022)$ & $(0.016)$ & $(0.017)$ \\
\hline Constant & $-4.697 * * *$ & $-4.358 * * *$ & -4.478 \\
\hline & $(0.095)$ & $(0.079)$ & $(0.086)$ \\
\hline Region FE & YES & YES & YES \\
\hline Cohort FE & YES & YES & YES \\
\hline Observations & 45,632 & 45,632 & 45,632 \\
\hline Number of respondents & 5,622 & 5,622 & 5,622 \\
\hline
\end{tabular}

Notes: Children conceived during first marriage include only those children who were born during or after the ninth month of marriage. The sample consists of men and women who were at least 21 years old when they first married. Column (1) shows results using dummies for the number of siblings of respondent as covariates. Column (2) includes as covariate a dummy indicating whether the respondent has experienced a multiple birth. Column (3) presents results after using both sets of variables simultaneously as covariates. *** Significant at the $1 \%$ level, ** Significant at the 5\% level, * Significant at the $10 \%$ level. 
Table B. - Children Conceived During First Marriage and Risk of Marital Dissolution: Analysis by Educational Level: Random and Fixed Effects (Dependent Variable: Risk of Marital Dissolution)

\begin{tabular}{|c|c|c|c|c|c|c|}
\hline & $(1)$ & $(4)$ & $(2)$ & $(5)$ & $(3)$ & $(6)$ \\
\hline Number children conceived within marriage & $\begin{array}{c}-0.008 \\
(0.008)\end{array}$ & $\begin{array}{c}-0.008 \\
(0.009)\end{array}$ & $\begin{array}{c}-0.012 * * * \\
(0.003)\end{array}$ & $\begin{array}{c}-0.011 * * * \\
(0.004)\end{array}$ & $\begin{array}{c}-0.016 * * * \\
(0.002)\end{array}$ & $\begin{array}{c}-0.017 * * * \\
(0.002)\end{array}$ \\
\hline Gender & $\begin{array}{c}-0.066 * * * \\
(0.025)\end{array}$ & & $\begin{array}{c}-0.008 \\
(0.009)\end{array}$ & & $\begin{array}{c}-0.015 * * \\
(0.006)\end{array}$ & \\
\hline Age & $\begin{array}{c}0.041^{* * *} \\
(0.006)\end{array}$ & $\begin{array}{c}0.055 * * * \\
(0.007)\end{array}$ & $\begin{array}{c}0.032 * * * \\
(0.003)\end{array}$ & $\begin{array}{c}0.043 * * * \\
(0.003)\end{array}$ & $\begin{array}{c}0.025 * * * \\
(0.002)\end{array}$ & $\begin{array}{c}0.031^{* * *} \\
(0.002)\end{array}$ \\
\hline Age squared & $\begin{array}{c}-0.001 * * * \\
(0.0001)\end{array}$ & $\begin{array}{c}-0.001 * * * \\
(0.0001)\end{array}$ & $\begin{array}{c}-0.0004 * * * \\
(0.00004)\end{array}$ & $\begin{array}{l}-0.001 * * * \\
(0.00004)\end{array}$ & $\begin{array}{c}-0.0003 * * * \\
(0.00003)\end{array}$ & $\begin{array}{c}-0.0004^{* * *} \\
(0.00003)\end{array}$ \\
\hline Wife five years older & $\begin{array}{c}0.079 \\
(0.050)\end{array}$ & & $\begin{array}{c}0.034 \\
(0.023)\end{array}$ & & $\begin{array}{c}0.019 \\
(0.021)\end{array}$ & \\
\hline Husband five years older & $\begin{array}{c}0.025 \\
(0.024)\end{array}$ & & $\begin{array}{c}0.009 \\
(0.011)\end{array}$ & & $\begin{array}{c}0.026 * * * \\
(0.009)\end{array}$ & \\
\hline Father in household in 1979 & $\begin{array}{c}-0.056^{* *} \\
(0.023)\end{array}$ & & $\begin{array}{c}-0.036 * * * \\
(0.010)\end{array}$ & & $\begin{array}{l}-0.012 \\
(0.008)\end{array}$ & \\
\hline Without father figure in 1979 & $\begin{array}{l}-0.056 \\
(0.095)\end{array}$ & & $\begin{array}{l}-0.015 \\
(0.040)\end{array}$ & & $\begin{array}{l}-0.007 \\
(0.037)\end{array}$ & \\
\hline Charged illegal by 1980 & $\begin{array}{c}0.080 * * * \\
(0.031)\end{array}$ & & $\begin{array}{c}0.037 * * \\
(0.015)\end{array}$ & & $\begin{array}{c}0.038 * * \\
(0.017)\end{array}$ & \\
\hline Age first marriage & $\begin{array}{c}-0.011 * * * \\
(0.003)\end{array}$ & & $\begin{array}{c}-0.009 * * * \\
(0.001)\end{array}$ & & $\begin{array}{c}-0.008 * * * \\
(0.001)\end{array}$ & \\
\hline Child before marriage & $\begin{array}{c}0.001 \\
(0.025)\end{array}$ & & $\begin{array}{c}0.053^{* * *} \\
(0.013)\end{array}$ & & $\begin{array}{c}0.042 * * * \\
(0.014)\end{array}$ & \\
\hline Race: hispanic & $\begin{array}{l}-0.035 \\
(0.028)\end{array}$ & & $\begin{array}{l}-0.006 \\
(0.013)\end{array}$ & & $\begin{array}{c}0.013 \\
(0.010)\end{array}$ & \\
\hline Race: black & $\begin{array}{c}0.065 * * \\
(0.031)\end{array}$ & & $\begin{array}{c}0.043^{* * *} \\
(0.014)\end{array}$ & & $\begin{array}{c}0.049 * * * \\
(0.010)\end{array}$ & \\
\hline Same education & $\begin{array}{l}-0.026 \\
(0.021)\end{array}$ & $\begin{array}{c}-0.042 \\
(0.035)\end{array}$ & $\begin{array}{l}-0.008 \\
(0.008)\end{array}$ & $\begin{array}{c}-0.024^{* *} \\
(0.012)\end{array}$ & $\begin{array}{l}-0.010 \\
(0.006)\end{array}$ & $\begin{array}{c}0.006 \\
(0.009)\end{array}$ \\
\hline Respondent more educated than spouse & & & $\begin{array}{c}0.008 \\
(0.014)\end{array}$ & $\begin{array}{c}-0.038 * \\
(0.021)\end{array}$ & & \\
\hline Constant & $\begin{array}{c}-0.233^{*} \\
(0.122)\end{array}$ & $\begin{array}{c}-0.880 * * * \\
(0.129)\end{array}$ & $\begin{array}{c}-0.211 * * * \\
(0.051)\end{array}$ & $\begin{array}{c}-0.737 * * * \\
(0.057)\end{array}$ & $\begin{array}{c}-0.198 * * * \\
(0.036)\end{array}$ & $\begin{array}{c}-0.580 * * * \\
(0.040)\end{array}$ \\
\hline Region FE & YES & YES & YES & YES & YES & YES \\
\hline Cohort FE & YES & YES & YES & YES & YES & YES \\
\hline Observations & 3,391 & 3,391 & 16,860 & 16,860 & 25,381 & 25,381 \\
\hline Number of respondents & 576 & 576 & 2,394 & 2,394 & 2,945 & 2,945 \\
\hline
\end{tabular}

Notes: Children conceived during first marriage include only those children who were born during or after the ninth month of marriage. The sample consists of men and women who were at least 21 years old when they first married. Columns (1), (3) and (5) include our estimates using a Random Effects technique, and Columns (2), (4) and (6) show results using a Fixed Effects technique. In addition, Columns (1) and (2) show results for the less educated interviewees, Columns (3) and (4) show results for the interviewees with an intermediate level of education, and Columns (5) and (6) show results for the interviewees with the highest level of education. *** Significant at the $1 \%$ level, ** Significant at the 5\% level, * Significant at the $10 \%$ level. 
Table C. - Children Conceived During First Marriage and Risk of Marital Dissolution: Random and Fixed Effects

(Dependent Variable: Risk of Marital Dissolution)

\begin{tabular}{|c|c|c|c|c|}
\hline & $(1)$ & $(2)$ & (3) & $(4)$ \\
\hline Number of children conceived within marriage & $\begin{array}{c}-0.015^{* * *} \\
(0.002)\end{array}$ & $\begin{array}{c}-0.015^{* * *} \\
(0.002)\end{array}$ & $\begin{array}{c}-0.015^{* * *} \\
(0.002)\end{array}$ & $\begin{array}{c}-0.015^{* * *} \\
(0.002)\end{array}$ \\
\hline Gender & $\begin{array}{c}-0.013 * * \\
(0.005)\end{array}$ & $\begin{array}{c}-0.013^{* *} \\
(0.005)\end{array}$ & $\begin{array}{c}-0.013 * * \\
(0.005)\end{array}$ & \\
\hline Age & $\begin{array}{c}0.030 * * * \\
(0.002)\end{array}$ & $\begin{array}{c}0.030 * * * \\
(0.002)\end{array}$ & $\begin{array}{c}0.030^{* * *} \\
(0.002)\end{array}$ & $\begin{array}{c}0.039 * * * \\
(0.002)\end{array}$ \\
\hline Age squared & $\begin{array}{c}-0.0003^{* * *} \\
(0.00002)\end{array}$ & $\begin{array}{c}-0.0003 * * * \\
(0.00002)\end{array}$ & $\begin{array}{c}-0.0003^{* * *} \\
(0.00002)\end{array}$ & $\begin{array}{c}-0.0005^{* * *} \\
(0.00002)\end{array}$ \\
\hline Wife five years older & $\begin{array}{c}0.038 * * \\
(0.015)\end{array}$ & $\begin{array}{c}0.038^{* *} \\
(0.015)\end{array}$ & $\begin{array}{c}0.037 * * \\
(0.015)\end{array}$ & \\
\hline Husband five years older & $\begin{array}{c}0.018 * * * \\
(0.007)\end{array}$ & $\begin{array}{c}0.018 * * * \\
(0.007)\end{array}$ & $\begin{array}{c}0.018 * * * \\
(0.007)\end{array}$ & \\
\hline Highest education: lowest level & $\begin{array}{c}0.046^{* * *} \\
(0.011)\end{array}$ & $\begin{array}{c}0.045 * * * \\
(0.011)\end{array}$ & $\begin{array}{c}0.044 * * * \\
(0.011)\end{array}$ & $\begin{array}{l}-0.038 * \\
(0.022)\end{array}$ \\
\hline Highest education: high school level & $\begin{array}{c}0.037 * * * \\
(0.006)\end{array}$ & $\begin{array}{c}0.037^{* * *} \\
(0.006)\end{array}$ & $\begin{array}{c}0.036 * * * \\
(0.006)\end{array}$ & $\begin{array}{l}-0.010 \\
(0.013)\end{array}$ \\
\hline Highest education: college level & $\begin{array}{c}0.032 * * * \\
(0.005)\end{array}$ & $\begin{array}{c}0.032 * * * \\
(0.005)\end{array}$ & $\begin{array}{c}0.032 * * * \\
(0.005)\end{array}$ & $\begin{array}{c}0.019 * * \\
(0.008)\end{array}$ \\
\hline Highest education spouse: lowest level & $\begin{array}{c}0.019^{*} \\
(0.010)\end{array}$ & $\begin{array}{l}0.019^{*} \\
(0.010)\end{array}$ & $\begin{array}{l}0.018^{*} \\
(0.010)\end{array}$ & $\begin{array}{c}-0.027^{*} \\
(0.015)\end{array}$ \\
\hline Highest education spouse: high school level & $\begin{array}{l}0.010^{*} \\
(0.006)\end{array}$ & $\begin{array}{l}0.010^{*} \\
(0.006)\end{array}$ & $\begin{array}{l}0.010^{*} \\
(0.006)\end{array}$ & $\begin{array}{c}-0.012 \\
(0.010)\end{array}$ \\
\hline Highest education spouse: college level & $\begin{array}{l}0.010^{*} \\
(0.005)\end{array}$ & $\begin{array}{l}0.010^{*} \\
(0.005)\end{array}$ & $\begin{array}{l}0.010^{*} \\
(0.005)\end{array}$ & $\begin{array}{l}-0.001 \\
(0.008)\end{array}$ \\
\hline Father in household in 1979 & $\begin{array}{c}-0.021^{* * *} \\
(0.006)\end{array}$ & $\begin{array}{c}-0.021 * * * \\
(0.006)\end{array}$ & $\begin{array}{c}-0.027 * * * \\
(0.006)\end{array}$ & \\
\hline Without father figure in 1979 & $\begin{array}{l}-0.006 \\
(0.029)\end{array}$ & $\begin{array}{l}-0.007 \\
(0.029)\end{array}$ & $\begin{array}{l}-0.010 \\
(0.029)\end{array}$ & \\
\hline Charged illegal by 1980 & $\begin{array}{c}0.045^{* * *} \\
(0.011)\end{array}$ & $\begin{array}{c}0.044^{* * *} \\
(0.011)\end{array}$ & $\begin{array}{c}0.046^{* * *} \\
(0.011)\end{array}$ & \\
\hline Age first marriage & $\begin{array}{c}-0.008 * * * \\
(0.001)\end{array}$ & $\begin{array}{c}-0.008 * * * \\
(0.001)\end{array}$ & $\begin{array}{c}-0.008 * * * \\
(0.001)\end{array}$ & \\
\hline Child before marriage & $\begin{array}{c}0.047 * * * \\
(0.009)\end{array}$ & $\begin{array}{c}0.047 * * * \\
(0.009)\end{array}$ & $\begin{array}{c}0.046^{* * *} \\
(0.009)\end{array}$ & \\
\hline Race: hispanic & $\begin{array}{c}0.000 \\
(0.007)\end{array}$ & $\begin{array}{c}-0.003 \\
(0.008)\end{array}$ & $\begin{array}{c}-0.004 \\
(0.008)\end{array}$ & \\
\hline Race: black & $\begin{array}{c}0.051 * * * \\
(0.008)\end{array}$ & $\begin{array}{c}0.051 * * * \\
(0.008)\end{array}$ & $\begin{array}{c}0.049 * * * \\
(0.008)\end{array}$ & \\
\hline Constant & $\begin{array}{c}-0.287 * * * \\
(0.028)\end{array}$ & $\begin{array}{c}-0.294 * * * \\
(0.028)\end{array}$ & $\begin{array}{c}-0.258^{* * *} \\
(0.030)\end{array}$ & $\begin{array}{c}-0.678^{* * *} \\
(0.034)\end{array}$ \\
\hline Region FE & NO & YES & YES & YES \\
\hline Cohort FE & NO & NO & YES & YES \\
\hline Observations & 45,632 & 45,632 & 45,632 & 45,632 \\
\hline Number of respondents & 5,622 & 5,622 & 5,622 & 5,622 \\
\hline
\end{tabular}

Notes: Children conceived during first marriage include only those children who were born during or after the ninth month of marriage. The sample consists of men and women who were at least 21 years old when they first married. Columns (1), (2) and (3) show results for the Random Effects methodology and Column (4) shows results for the Fixed Effects methodology. Column (1) includes controls for gender, age, and the age gap, the education of respondent and his/her spouse, family structure when young, risk activities when young, age at first marriage, whether there exists a child conceived before first marriage, and race. Column (2) adds controls for the region of current residence. Columns (3) and (4) also include controls for the cohort of respondent. *** Significant at the $1 \%$ level, ** Significant at the 5\% level, * Significant at the $10 \%$ level. 



\section{APPENDIX B:}

Table A. - Data Sources and Definition of Variables

\begin{tabular}{|c|c|c|}
\hline Variable & Definition & Source \\
\hline \multicolumn{3}{|l|}{ Dependent Variable } \\
\hline Divorce & This variable takes value 0 while the interviewee is married, and value 1 the year before the divorce occurs. & NLSY79 \\
\hline \multicolumn{3}{|l|}{ Variables of Interest } \\
\hline Children conceived during marriage & Number of children conceived during first marriage. & NLSY79 \\
\hline Children conceived during marriage Under 6 & Number of children conceived during first marriage who are six years old or younger. & NLSY79 \\
\hline Children conceived during marriage Under 10 & Number of children conceived during first marriage who are ten years old or younger. & NLSY79 \\
\hline All children conceived & Number of children conceived before and during first marriage. & NLSY79 \\
\hline Children conceived before marriage & Number of children conceived before first marriage. & NLSY79 \\
\hline \multicolumn{3}{|l|}{ Control Variables } \\
\hline Age & Variable indicating the age of interviewee. & NLSY79 \\
\hline Age squared & Variable indicating the square of the age of interviewee. & NLSY79 \\
\hline Wife five years older & This variable takes value 1 if the wife is, at least, five years older than her husband and 0 otherwise. & NLSY79 \\
\hline Husband five years older & This variable takes value 1 if the husband is, at least, five years older than his wife and 0 otherwise. & NLSY79 \\
\hline Same age & This variable takes value 1 if there is an age gap between spouses of less than five years and 0 otherwise. & NLSY79 \\
\hline Highest education: lowest level & This variable takes value 1 if the highest level of education of the interviewee is lower than $12^{\text {th }}$ grade and 0 otherwise. & NLSY79 \\
\hline Highest education: high school level & This variable takes value 1 if the highest level of education of the interviewee is the $12^{\text {th }}$ grade (completed high school) and 0 otherwise. & NLSY79 \\
\hline Highest education: college level & This variable takes value 1 if the highest level of education of the interviewee is between the first and the third year of college and 0 otherwise. & NLSY79 \\
\hline Highest education: more than college level & This variable takes value 1 if the highest level of education of the interviewee is the fourth year of college or more and 0 otherwise. & NLSY79 \\
\hline Highest education spouse: lowest level & This variable takes value 1 if the highest level of education of the interviewee's spouse is lower than $12^{\text {th }}$ grade and 0 otherwise. & NLSY79 \\
\hline Highest education spouse: college level & $\begin{array}{l}\text { This variable takes value } 1 \text { if the highest level of education of the interviewee's spouse is between the first and the third year of college and } 0 \\
\text { otherwise. }\end{array}$ & NLSY79 \\
\hline Highest education spouse: more than college level & This variable takes value 1 if the highest level of education of the interviewee's spouse is the fourth year of college or more and 0 otherwise. & NLSY79 \\
\hline Father in household in 1979 & This variable takes value 1 if respondent's father or stepfather is in household in 1979 and 0 otherwise. & NLSY79 \\
\hline Father out household in 1979 & This variable takes value 1 if respondent's father or stepfather is not in household in 1979 and 0 otherwise. & NLSY79 \\
\hline Without father figure in 1979 & This variable takes value 1 if respondent has no father figure in 1979 and 0 otherwise. & NLSY79 \\
\hline Charged illegal by 1980 & This variable takes value 1 if respondent has ever been charged with illegal activity, excluding minor traffic offenses, by 1980 and 0 otherwise. & NLSY79 \\
\hline Age at first marriage & Variable indicating the age of respondent when first marriage began. & NLSY79 \\
\hline Child before marriage & This variable takes value 1 if first children were conceived before first marriage and 0 otherwise. & NLSY79 \\
\hline Race: Hispanic & This variable takes value 1 if respondent's race is hispanic and 0 otherwise. & NLSY79 \\
\hline Race: black & This variable takes value 1 if respondent's race is black and 0 otherwise. & NLSY79 \\
\hline Race: other & This variable takes value 1 if respondent's race is other than black or hispanic and 0 otherwise. & NLSY79 \\
\hline Region FE & Dummy variables for the region of residence (North East (omitted), North Central, South, and West). & NLSY79 \\
\hline Cohort FE & Dummy variables for the cohort of respondent (from 1957 to 1964). & NLSY79 \\
\hline
\end{tabular}


Family income indicator

Family income indicator squared

Religion raised

\section{Living urban}

Employed

Spouse employed

Same education

Respondent more educated than spouse

Respondent less educated than spouse

\section{Instrumental Variables}

No siblings

One sibling

Two siblings

Three siblings

Four or more siblings

Multiple birth

First sex before 16 years old

First sex between 16 and 18 years old

First sex after 16 years old

No sex by the period 1983-1985
Variable that relates the total net family income and the number and age of household members.

NLSY79

Dummy variables for the religion under which respondent was raised (protestant, roman catholic, jewish, other religion, and no religion NLSY79 (omitted)).

This variable takes value 1 if respondent's current residence is urban and 0 otherwise.

This variable takes value 1 if respondent's employment status is employed and 0 otherwise.

NLSY79

NLSY79

This variable takes value 1 if respondent's spouse's employment status is employed and 0 otherwise. _ NLSY79

This variable takes value 1 if respondent's education is the same as his/her spouse and 0 otherwise. NLSY79

This variable takes value 1 if respondent's education is higher than his/her spouse and 0 otherwise. NLSY79

This variable takes value 1 if respondent's education is lower than his/her spouse and 0 otherwise.

This variable takes value 1 if respondent has no siblings and 0 otherwise.

NLSY79

This variable takes value 1 if respondent has one sibling and 0 otherwise.

NLSY79

This variable takes value 1 if respondent has three siblings and 0 otherwise.

NLSY79

This variable takes value 1 if respondent has four or more siblings and 0 otherwise.

Nise.

This variable takes value 1 if respondent has experienced a multiple birth during first marriage and 0 otherwise. NLSY79

This variable takes value 1 if respondent had his/her first sexual intercourse before 16 years old.

This variable takes value 1 if respondent had his/her first sexual intercourse between 16 and 18 years old. NLSY79

This variable takes value 1 if respondent had his/her first sexual intercourse after 18 years old.

. 1 if respondent had not had sex by the peiod 1983-1985. 